\title{
Change of Mortality Patterns of Respiratory Diseases during the Spread of the Pandemic of COVID-19: An Applied Geographical Study in Assiut Governorate, Egypt
}

\begin{abstract}
Ahmed Ali Ahmed Ali*
ABSTRACT

Respiratory diseases are among the main causes of mortality, morbidity and hospitalization. They can be attributed to many environmental, economical, social and behavioral factors. Their seasonality varies according to climate change. Their map of distribution as well as their numbers has varied both spatially and temporally as respiratory syndrome known as Covid-19 spread.The latter is the hugest challenge that quickens the spread of respiratory diseases all over the world. It spreads speedily in many countries since the announcement about the first case in China in December 2019. The disease is declared as pandemic in March 2020. Egypt has announced the first case of infection of Covid-19 and the first case of mortality of the same disease on 14 February 2020 and on 8 March 2020 respectively.

The current research aims at analyzing time and place variances as well as the demographic differences of the numbers of mortality of respiratory diseases in Assiut governorate. It also studies their patterns of change describing the possible reasons behind them. This assists in assigning the rate of mortality and its rise, which is possibly related to the spread of Covid-19. Increase of mortalities could be due to cases that were not checked to be recognized as either infected of Covid-19 or not. The current study is a descriptive analytical one among many other researches and studies in varied fields that attempt to find means of facing Covid-19 which shares in changing the map of mortality of respiratory diseases.
\end{abstract}

Knowing the geographical distribution and mortality rates of respiratory diseases as well as their change whether according to place or season contributes to recognizing the spatial foci of these diseases. That helps in preparing for facing their different influences. Measuring the dynamic of mortality of respiratory diseases eases the interaction between the strategies of health care units and the changed trends. That allows the first to handle the increased rates of infection or even their decrease. Drawing maps of distribution of respiratory diseases in general and Covid-19 in particular is essential for supporting the exerted efforts working on raising the awareness of the population. They also facilitate the process of monitoring done by the responsible entities, and direct the departments of quarantine at the hospitals of the governorate and the medical centers to take needed precautions according to the map of mortality of respiratory diseases in the governorate. [Bul. Soc. Géog. d'Égypte, 2021, 94: 69-109]

Key Words: Respiratory Diseases, COVID-19, Mortality Patterns, Assiut Governorate.

Department of Geography \& GIS, Faculty of Arts - Assiut University, Egypt.

For Correspondence: e-mail: ahmed.ali@aun.edu.eg 


\section{Introduction}

Respiratory diseases are considered of general health problems at all countries of the world. They increase morbidity levels and mortality particularly in developing countries. They have caused about 238 million deaths globally in 2016 (GBD, 2017). This makes them the fifth main cause of mortality in general and the main contagious reason of mortality at different ages over the last 3 decades. Mortality of respiratory diseases represents about $6 \%$ of yearly mortality globally (WHO, 2020).

Respiratory diseases are closely related to meteorological conditions as both high and low temperatures influence them. High and low temperatures worsen the symptoms of respiratory diseases particularly among those who already suffer bad health conditions (EPA, 2011). Decrease in temperatures have a negative impact on one's health represented in narrowing of respiratory airways and retreat in lungs' functions. On the other hand, rise of temperature can increase allergy diseases either as a consequence of much pollens or because of the extend of their season which in turn leads to worsening of the symptoms of respiratory diseases. In addition to that, rain fall facilitates the spread of respiratory diseases (Siyan et al., 2020).

Some studies confirmed that elderly people along with patients of respiratory diseases are in jeopardy of suffering from problems in the functions of Cardiac Circulation which affects lungs. On the other hand, low temperatures might cause peripheral blood stasis leading to much blood in the lungs and as such worsening the situation (Juliana and Stefan, 2012).

Hot climate speeds the formation of Ozone layer. Inhaling air containing ozone minimizes the function of lungs, maximizes the symptoms of respiratory diseases, and worsens the conditions of those who are asthmatic or have lung fibrosis. Again, being exposed to Ozone leads to early death particularly those who suffer from heart and lung diseases (Iuliano et al., 2017).

Previous studies indicated that in addition to environmental factors as climate change and air pollution, there are many elements that negatively affect the wellbeing of the respiratory system and lead to mortality of patients suffering from respiratory diseases. These elements are either social or economical like bad housing conditions, low social and economical levels, low educational levels, demographic factors including age, sex and race and behavioral factors like smoking (Viana et al., 2017; Wisdom et al., 2020). 
Air pollution threatens the wellbeing of the respiratory system and worsens its chronic diseases as chronic asthma, pulmonary embolism, etc. According to reports of $\mathrm{WHO}, 92 \%$ of world's population lives at places whose air is not good and where dangerous factors related to climate and environment and that threaten the wellbeing of the respiratory systems do exist (Abolfazl et al., 2020).

What proves the danger of respiratory diseases is that pandemic flu killed between 20-50 million in 1918, which is more than those who died in world war 1 . Today, seasonal flu still massively contributes to the increased numbers of patients of respiratory diseases and their mortality all over the world (Sahai et al., 2021).

Respiratory diseases range from bronchitis, pneumonia, lung fibrosis, to pneumonia of unidentified organisms. The latter can be caused by many viruses of which about 6-9 were discovered in the late years. Lately, also Covid (Kazory et al., 2020) which is responsible for the admission of about $65 \%$ of patients of respiratory diseases to hospitals appeared ${ }^{(1)}$ (Sun et al., 2020).

Corona viruses constitute a large family of viruses that cause respiratory diseases ranging from common cold to serious diseases like Middle East Respiratory Syndrome (MERS-COV), Acute Respiratory Syndrome (SARSCOV-1, 2), novel corona virus known as Covid-19 which is a new unprecedented genus that is found for the first time among humans. The original name of the virus is Sever Acute Respiratory Syndrome (SARS$\mathrm{COV}, 1,2)$. The disease it causes is named by the world health organization (WHO, 2020).

Corona virus disease is one of the biggest challenges that led to the spread of respiratory diseases all over the world. The virus spread speedily in many countries at varied rates since the announcement about the first case in Hubei, China in December 2019. That led the world health organization to declare it pandemic in March 2020 (Wu et al., 2020).

(1) Medical reports that have been recently published refer to the recurrence of the common clinical symptoms of Covid 19 among humans. According to what specialists mentioned, the following are the most common symptoms of Covid 19 - fever $(82 \%)$, cough $(61 \%)$, muscle pain / fatigue (36\%), shortness of breath (26\%), headache (12\%), sore throat (10\%), and gastrointestinal symptoms (9\%) (Sun et al., 2020). 
Egypt has announced the first case of Covid 19 on 14th February 2020. It's the second country in the regional office of Middle East world health organization which confirms cases of infection after United Arab Emirates and the first African country to announce infection (Abed Alah et al., 2020). The infected cases were checked and laboratory tests were performed at Cairo International Airport. The first infected person was a Chinese citizen on whom the symptoms did not show up. First mortality case because of Covid 19 was announced in Egypt on 8th March 2020 of a German citizen, who was 60 years old and came to Egypt as a tourist. He arrived a week before his death. He suffered fever, was admitted to hospital immediately, yet, his health deteriorated. He passed away on 19th March (Onafeso et al., 2021).

Away from the direct effects that Covid-19 has on humans, it also has influences that vary from place to another. This variation is reflected in the number of those infected and number of those passing away ( $\mathrm{Wu}$ et al., 2020). In addition to the indirect impact on economy, many governments all over the world has executed different levels of lockdown and policies of "staying home" in order to set a limit for this pandemic. Such procedures led to deterioration in the global economical activities, which in turn largely minimized the levels of air pollution at many areas of the world. After 2 weeks of lockdown, 27 countries reported decrease of the levels of nitrogen dioxide and Ozone. This was found through analyzing the data collected via satellites during February and March 2020 (Patel et al., 2020; Shouraseni and Robert, 2021).

Studies concluded that a massive improve in the quality of air at all levels has occurred. Levels of nitrogen dioxide and particles hanging in the atmosphere decreased by 50\% (Shouraseni and Robert, 2021). These two were proved as the cause behind the death of 272,000 persons of chronic obstructive pulmonary, 110600 by heart diseases and 14800 by lung cancer (Chowdhury and Dey, 2016).

In that sense we dare to say that even though mortality rates of respiratory diseases has increased due to the spread of Covid 19, there is a decrease in mortality rate of other respiratory diseases such as asthma, chest allergy and lung fibrosis. Hence, Covid 19 has changed the patterns of mortality which is the theme that this research reveals. The current study aims at analyzing the change of the patterns of mortality of respiratory diseases during the spread of Covid-19 in Assiut governorate. 


\section{The Problem of the Study and its Objectives:}

During one year, Covid-19 had a huge impact on the whole world. After being described for the first time on 7 January 2020, Covid-19 rapidly spread in the world. On $7^{\text {th }}$ January 2021, estimations revealed that there were confirmed 146809 cases of infection and 8209 fatalities after one year of declaring Covid-19 as a disease (Egyptian Ministry of Health, 2021).

Recognizing the differences in the numbers of fatalities of respiratory diseases according to the geographical areas and understanding their change of patterns aim at spotting the spatial foci of diseases and getting ready to face their effects. Drawing maps about; the seriousness of respiratory diseases in general, and the possibilities of being exposed to Covid-19 is a crucial matter for handling diseases. The current study aims at recognizing the time trends of the mortalities of respiratory diseases and their dynamics each now and then in order to know; how far they are spread, in what ways, and to understand their natures. This assists in reaching estimations, and predictions that can be used by health care units to adapt their strategies according to the changed trends of the diseases and hence become ready to handle either the increase in the numbers of infected cases or their fall.

\section{The Study Area:}

The location of a certain place impacts man's health as it relates to the different elements of climate and the diseases attached to them (Sharaf, 2003). The geographical site of any location may represent a threat to its inhabitants' lives particularly if it is close to places that are home to diseases and epidemics.

Assiut is a governorate in Upper Egypt. It is bordered by El Minia governorate from the north, by Sohag governorate from the south, Red Sea governorate from the east and New Valley governorate from the west. Assiut governorate is in the shape of a bar that extends for $130 \mathrm{Kms}$ by the bank of the river Nile. It lies at latitudes of ${ }^{\circ} 26^{\prime} 45$ and ${ }^{\circ} 27^{\prime} 45$ to the north and between longitudes ${ }^{\circ} 30$ ' 45 to the north and ${ }^{\circ} 31$ ' 45 to the east. It is about $25929 \mathrm{Km} \mathrm{sq}$ which is $2.59 \%$ of the total area of Egypt. Its inhabited area is about $1562 \mathrm{Km}$ sq. It's population is about 4383289 persons according to the census of 2017. Administratively, Assiut governorate is made of 11 districts, 52 local units and 235 villages (CAPMS, 2018).

The location of the governorate had shaped its climate which is one of the most natural factors affecting man's health. Hippocrates noticed the 
impact of seasonal change on man's health, he said; "whoever wants to study medicine has to learn about the seasons of the year at first" (Elsabawy, 2007). Examining some epidemic diseases revealed that they match with certain patterns of climate as some of them are active in certain seasons and inactive in others. These diseases are even described by the names of certain seasons like, spring conjunctivitis (Sharaf, 2003). Seasonal factors interact with social, economical and environmental factors in influencing mortality rates. Certain groups of inhabitants are sometimes unable to defend themselves against climate change even though it is not the sole factor responsible for mortality (Gaber, 2003).

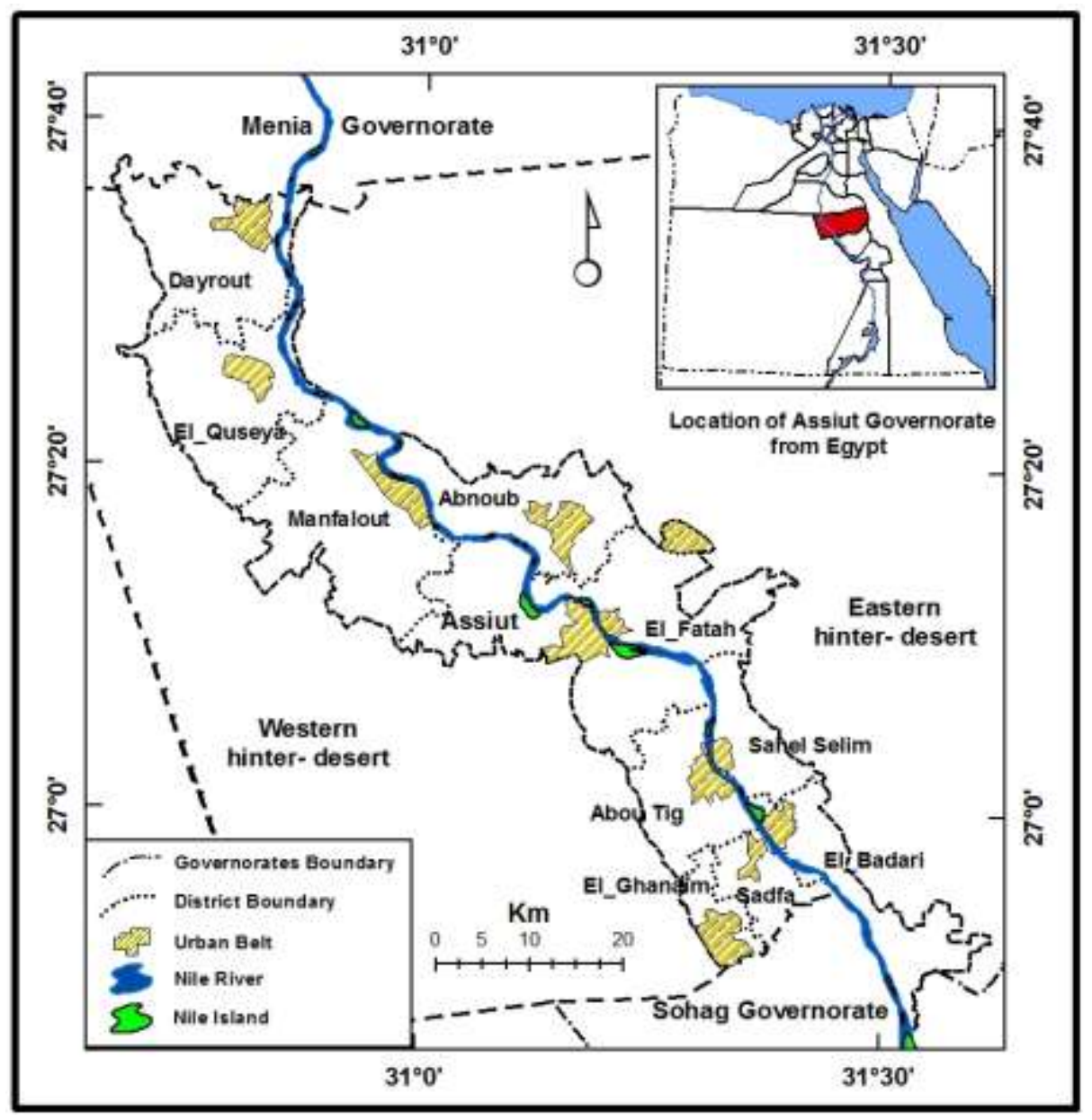

Figure 1. Administrative Division of Assiut Governorate in 2020. 


\section{Sources of the Study \\ Statistics and Reports:}

- Central Agency for Public Mobilization and Statistics (CAPMS). Results of the census of Assiut's population, 2017.

- Directorate of health and population, administration of health affairs, unpublished reports, 2019.

- Ministry of Health and population, national information district of the ministry of health, health information systems unit, unpublished reports, 2021.

\section{Maps:}

- Central Agency for Public Mobilization and Statistics (CAPMS). Geographic information systems unit, map of administrative division of Assiut governorate, scale (1: 500000), 2019.

- Central Agency for Public Mobilization and Statistics (CAPMS). Geographic information systems unit, map of administrative division of Arab Republic of Egypt, scale (1: 500000), 2018.

\section{Literature Review:}

A number of studies related to the topic of the current study have been reviewed. Some of these are about respiratory diseases; others have to do with Covid-19. Another group is about seasonal respiratory diseases and their geographical and environmental aspects. These studies are;-Geographic Variation in Racial Disparities in Mortality of Influenza and Pneumonia in the United States in the Pre-Corona virus Disease 2019 Era by (Sahai et al., 2021), the study presented by (Cesar et al., 2020) about Spatial estimation of chronic respiratory diseases based on machine learning procedures - an approach using remote sensing data and environmental variables in Quito, Ecuador, the study by (Wisdom et al., 2020) entitled: Spatial risk assessment of an emerging pandemic under data scargovernorate: A case of COVID-19 in Eswatini, the analytical study by Abed Alah et al. (2020) entitled; The first few cases and fatalities of Corona Virus Disease 2019 (COVID-19) in the Eastern Mediterranean Region, and the geographical study presented by Schneider et al. (2021), GIS-based identification of spatial variables enhancing heat and poor air quality in urban areas, Applied Geography.

Among the studies is one about Egypt presented by Raslan (2020), and entitled; Fractional mathematical modeling for epidemic prediction of COVID-19 in Egypt. Other studies are; the geographical study by Kuo and Hung, 2021, entitled; Regionalization for infection control: An algorithm for delineating containment zones considering the regularity of human mobility, an Applied Geographical study by Onafeso et al. (2021) about; Geographical 
trend analysis of COVID-19 pandemic onset in Africa, a study that has to do with planning to face the pandemic by Kobi et al. (2021) entitled; The COVID-19 pandemic challenge to the All-Hazards Approach for disaster planning, a study by Abolfazl et al. (2020), Predicting the hotspots of ageadjusted mortality rates of lower respiratory infection across the continental United States: Integration of GIS, spatial statistics and machine learning algorithms, a study by (Bing et al., 2021) entitled Seasonal association between viral causes of hospitalized acute lower respiratory infections and meteorological factors in China: a retrospective study, a study by Siyan et al. (2020) entitled Projecting impacts of temperature and population changes on respiratory disease mortality in Yancheng, and a study by Stefan et al., (2020) entitled; Mathematical modeling of COVID-19 fatality trends: Death kinetics law versus infection-to-death delay rule, a study by Iuliano et al. (2017) entitled; Estimates of global seasonal influenza-associated respiratory mortality: a modelling study, the medical geographical study by Vibhu et al. (2020) Trends and Geographic Variation in Acute Respiratory Failure and ARDS Mortality in the United States, study of GBD, (2017), Mortality, morbidity, and hospitalizations due to influenza lower respiratory tract infections, 2017: an analysis for the Global Burden of Disease Study 2017, and the study of (Shouraseni and Robert, 2021), about the Impact of the COVID-19 lockdown on air quality in the Delhi Metropolitan Region.

\section{Methodology:}

The study relied on many approaches particularly; the historical approach of tracking mortality of respiratory diseases and analyzing them, the fundamental systematic analytical approach in addition to the analytical quantitative method in order to study mortality of respiratory diseases recognizing the reasons, and clarifying the relativity between these two by statistics. According to these approaches, the plan of the study goes on as follows;

- First: Change in the distributional map of mortality rates of respiratory diseases from (2015-2020).

- Second: distributional patterns of mortality of respiratory diseases and their rates.

- Third: Time variance of mortality of respiratory diseases in Assiut governorate (1) Analyzing the coefficient of seasonal change of mortality of respiratory diseases. (2) Distribution of mortality of respiratory diseases over the districts of the governorate over the different months of the year.

- $\quad$ Fourth: Age structure of mortality of respiratory diseases.

- Conclusion. 


\section{First: Change in the distributional map of mortality rates of respiratory diseases from $(\mathbf{2 0 1 5 - 2 0 2 0})$ :}

Table (1) shows a rise in the participation of respiratory diseases in the burden of mortality all over the governorate of Assiut during the era from 2015- 2020. Respiratory diseases carries the burden of mortality of about 3060 persons in 2015, which represents about $10.85 \%$ of total mortality cases in the governorate. The governorate witnesses a noticeable decrease in its mortality rates in 2016 and that is in accordance with the general minimize in mortality rates of varied diseases during that year. Mortality of respiratory diseases is about 2646 cases representing $9.98 \%$ of the total number of mortality cases in 2016. The amount of decrease is by 414 cases, which is about $-23.53 \%$ of mortality cases in 2015 . Respiratory diseases slightly rises in 2017 by about 78 cases which is $2.95 \%$ of total mortality rate of respiratory diseases in 2016. Thus, the number of mortality cases becomes 2724 . Mortality of Respiratory diseases resembles $1.37 \%$ of the total mortality in 2017 .

Mortality of respiratory diseases continues to increase reaching 2813 cases in 2018, which is an increase of 89 cases and of $3.37 \%$. Respiratory diseases shares in the burden of mortality by $10.45 \%$ of the total mortality rate in the governorate in 2018. Its share increases in 2019 to become $10.77 \%$ of total mortality in the governorate as its mortality rises to be 2948 cases by $4.8 \%$, a noticeable rise that is estimated by 1370 mortality cases which is $46.47 \%$. Thus, fatalities of respiratory diseases in the governorate become 4318 cases which is $14.27 \%$ of the different reasons of fatality. Assiut governorate witnesses a general observed escalation in mortality by 2901 cases. Thus, the increase in mortality of respiratory diseases resembles $47.22 \%$ of the total increase of mortality rates in the governorate in the same year.

Concerning spatial levels, the rise and fall of mortality rates and their share in the general cases of mortality differ from district to another in the governorate during the studied era. Assiut district shares by $34.35 \%$ of total mortality of respiratory disease in the governorate in 2015. Assiut district is followed by the districts of; Dayrout, El-Quseya and El-Fatah. Together, they constitute $66 \%$ of mortality rate. Sahel Selim participates by the lowest average representing $2.42 \%$ of total mortality rate of respiratory diseases. Respiratory diseases participate by different numbers during 2015. The highest participation by respiratory diseases is in El-Fatah district by $20.58 \%$ of the total of mortality rate in the district. Respiratory diseases share by more than $10 \%$ of mortality rate in the districts of; Sadfa, Dayrout, ElQuseya, El-Ghanaim and Abou Tig. It is less than that in the rest of the districts reaching its lowest percentage in the district of Manfalout by $6.54 \%$ of the total mortality rate in the district. 


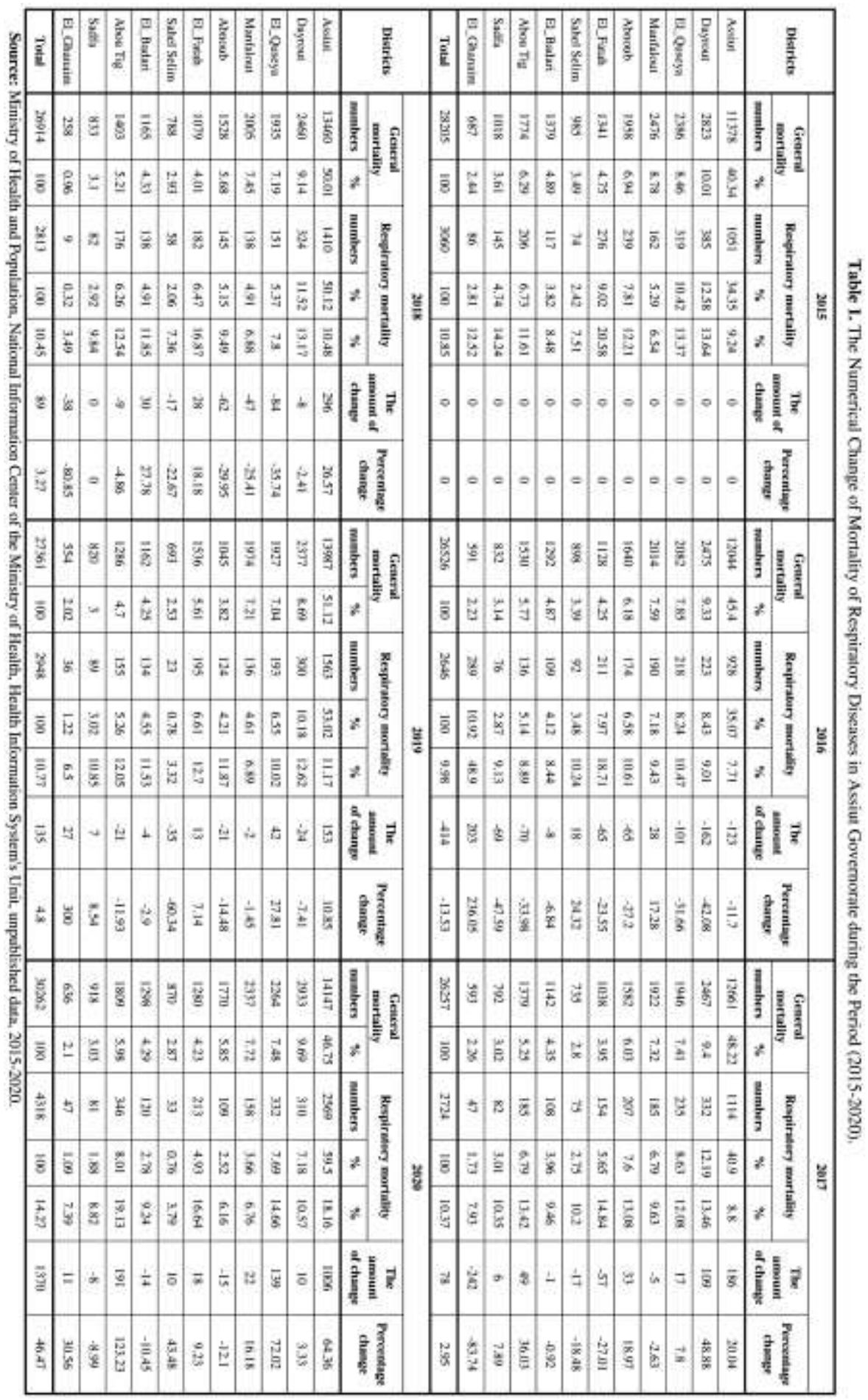




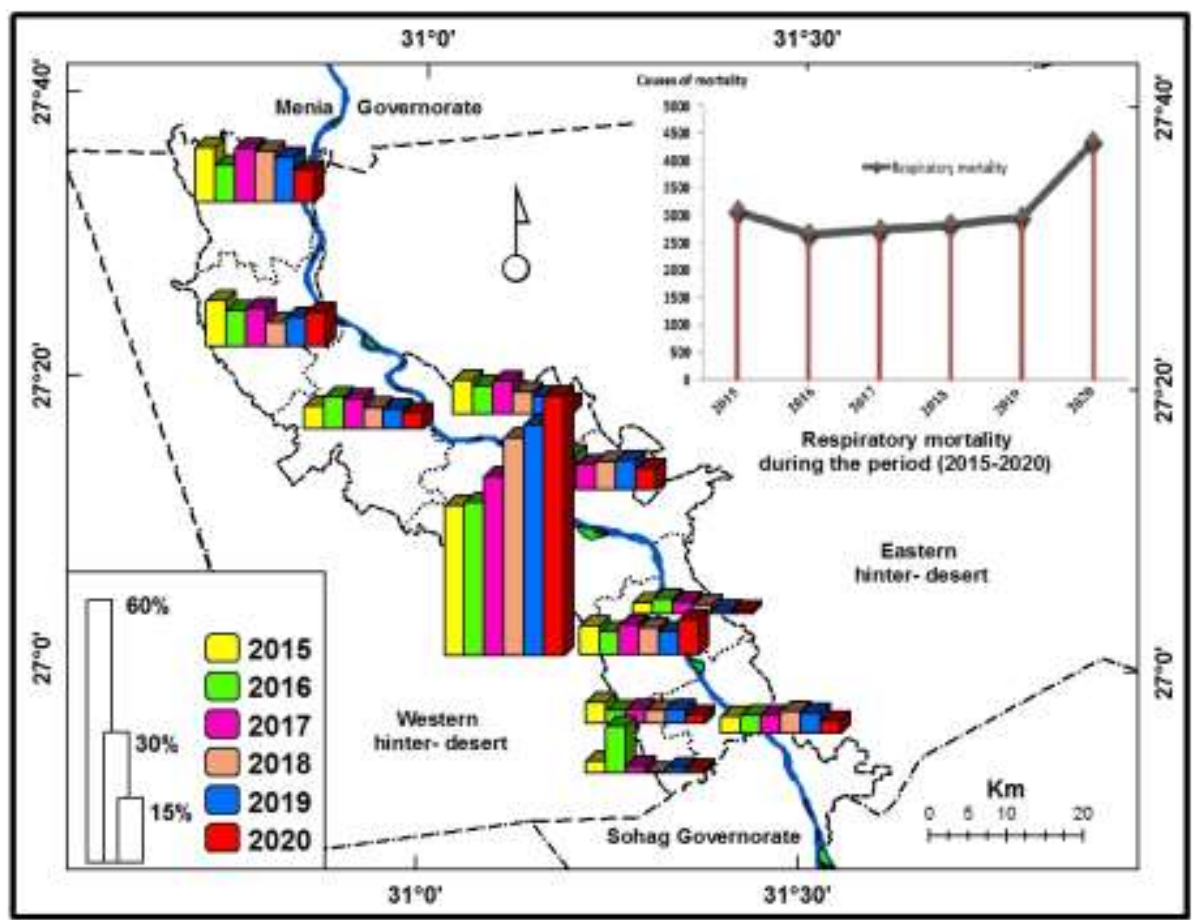

Figure 2. The Numerical Change of Mortality of Respiratory Diseases in Assiut Governorate during the period from (2015-2020).

In accordance with the general fall of fatality of respiratory diseases in 2016, most of the districts of Assiut governorate record varied levels of fall that is estimated by -162 cases in Dayrout which is about $-42 \%$. The highest percentage of fall is in Sadfa which records $-47.6 \%$ which is -69 of mortality. El-Badari, on the other hand records the least fall at all by $-6.84 \%$. Despite of the general fall in the numbers of fatalities, districts of El-Ghanaim, Manfalout and Sahel Selim witness a rise in fatalities of respiratory diseases recording $23.6 \%$ in El-Ghanaim which witness an increase by 203 cases of mortality. Mortality increases in Sahel Selim by $24.23 \%$ while in Manfalout by $17.28 \%$. what draws attention concerning the relative participation of fatalities of respiratory diseases is that it shares by about $48 \%$ of total mortality rate in El-Ghanaim which is about half of the total number of deaths in 2016. Respiratory diseases share by $18 \%$ of mortality in El-Fatah. Its lowest percentage of participation is in Assiut district by about $7.7 \%$. 
Despite of the overall escalation of mortality of respiratory diseases in Assiut governorate in 2017, some districts of the governorate witness a different condition. Dayrout, Assiut district, El-Quseya, Abnoub, Abou Tig and Sadfa witness a relative escalation in fatalities with Dayrout recording the highest numbers as mortality of respiratory diseases is $49 \%$ along with El-Quseya recording the lowest rise by not more than $7.8 \%$ of the total number of deaths in the district in 2016. All of; Manfalout, El-Fatah, Sahel Selim, El-Badari and El-Ghanaim record a decrease in fatalities of respiratory diseases with El-Ghanaim recording the highest decrease by $-83.74 \%$ and El-Badari recording the lowest decrease as fatalities fall down by only one case which is $-0.92 \%$ of mortality in the district in 2016 . Fatalities of respiratory diseases record their highest percentage of participation in El-Fatah by $14.84 \%$ while record their lowest participation among other reasons of mortality in El-Ghanaim district by $7.93 \%$ in 2017.

Except for Assiut district and El_Badari which witness a rise in mortality of respiratory diseases in 2018 by more than $25 \%$ of mortality in the previous year, the rest of the districts of the governorate witness a relative decrease. The highest percentage of decrease was in El-Ghanaim by $-80.85 \%$ while Dayrout record the lowest percentage of decrease by $-2.41 \%$ of the total of mortality rate in the district in the previous year. The percentage of participation of respiratory diseases in mortality rises to more than $12 \%$ in both Dayrout and Abou Tig. It exceeds $16 \%$ of the total number of fatalities in El-Fatah. Its lowest participation in mortality is in ElGhanaim as it doesn't go over 4\% of mortality in 2018 .

Assiut district, El-Quseya, El-Fatah, Sadfa and El-Ghanaim record an escalation in mortality in 2019. That escalation is about $300 \%$ in ElGhanaim that record 36 deaths more than those of 2018 which has only 9 cases. Mortalitiy in El-Quseya increases by 42 cases which is about $27.81 \%$ while increases in Assiut district by 153 cases which is about more than the previous year by $10.85 \%$. Mortality rises in Sadfa and El-Fatah, in 2018, by 7 cases and 13 cases respectively which is about 8.54 and $7.14 \%$. The percentages of participation by respiratory diseases as causes of mortality vary among the districts of the governorate. Respiratory diseases cause more than $12 \%$ of mortality cases both in Dayrout and Abou Tig. Sahel Selim has the least participation by $3.32 \%$ of deaths in 2019 .

Numbers of respiratory diseases go up in the governorate in 2020 as mentioned earlier. Mortality rates rise in the different districts of the 
governorate highly. Fatalities increase in Assiut district by more than 1000 cases representing $64 \%$ of mortality of respiratory diseases in 2019. Abou Tig has an increase of about 191 cases which is $123 \%$ of the district's deaths. Again, mortality of respiratory diseases in El-Quseya increased by 139 cases representing $72 \%$ of the district's deaths. Although the previous districts witness a noticeable increase of fatalities of respiratory diseases, some other districts like Abnoub, El-Badari, and Sadfa witness a decrease in fatalities of respiratory diseases under the spread of the pandemic. Participation of respiratory diseases in causing death increases in Abou Tig and Assiut district to be more than 18\%. Yet, it doesn't go beyond 7\% in Manfalout and Abnoub. Respiratory diseases resemble the least reason of mortality in Sahel Selim by $3.8 \%$.

A general Overview of the table indicates that the highest participation of respiratory diseases is in; Assiut district, El-Quseya and Abou Tig in 2020. In 2015, the highest participation of respiratory diseases is in; Dayrout, El-Fatah, Sadfa and Sahel Selim respectively. El-Badari district is the district that witnessed the highest share of respiratory diseases in 2018. Abnoub and Manfalout witness highest participation of respiratory diseases in 2017. In 2016, El-Ghanaim district records its highest participation.

\section{Second: Distributional patterns of mortality by respiratory diseases and their rates.}

Fatalities of respiratory diseases are 4318 in Assiut Governorate in 2020, while they are 3060 in 2016. This is an increase of $41.43 \%$ which is 1258 cases. Table (2) highlights a change in distribution of mortality of respiratory diseases. Bronchopneumonia comes as the first reason of mortality in 2015 by 915 cases. It carries the burden of mortality of about $30 \%$. Its participation also increases in 2020 to be 1840 cases which is $42.6 \%$. Unclassified respiratory failure comes second among the reasons of mortality of respiratory diseases by about $27 \%$ of deaths' burden. Its percentage rises in 2020 to be $28.76 \%$ of mortality burden of respiratory system in Assiut governorate.

Acute bronchitis comes third by 543 fatalities which is $17.75 \%$ in 2015 . It records a noticeable decrease in 2020 representing $5.77 \%$ of the total rate of mortality of respiratory diseases by not more than 250 cases. Pneumonia resulting from unidentified organisms comes fourth among mortality causes in 2015 by 223 death cases representing $7.3 \%$. Its share decreases in 2020 as it causes death only for 23 cases which is not more than $0.6 \%$ of death burden. 
Chest allergy, lung fibrosis, and asthma witness a decrease in their rates of mortality as well as in their relative participation in mortality of respiratory diseases. Mortality of chest allergy decreases from 125 cases which is $4.8 \%$ in 2015 to become 23 cases in 2020 representing not more than $0.53 \%$. Mortality of asthma drops to be 76 cases in 2020 representing $1.76 \%$ while it shares by $6.24 \%$ of mortality burden in 2015 . Fatalities of lung fibrosis drops by only 13 cases to be 108 cases in 2020 which is $2.5 \%$ of death burden. On the contrary, mortality of unclassified viral pneumonia and unclassified bacterial pneumonia leap as they cause death for not more than 23 cases which is $0.8 \%$ in 2015 while they cause death for 324 cases, in 2020 , which is $7.5 \%$ of mortality burden.

Mortality of novel Corona virus reaches 393 cases representing 9\% of mortality rates in the governorate in 2020. It comes third among the reasons of mortality of respiratory diseases by $9.1 \%$ in the governorate. Mortalities of novel Corona virus recorded in Assiut governorate are focused in the districts of Abou Tig, and Assiut district by 198 cases, which is $50.38 \%$ and 183 cases, which is $46.56 \%$ respectively. El-Badari district records 10 mortalities representing $2.5 \%$ of mortality of novel corona virus in the governorate in addition to 2 cases recoded in Dayrout and Sahel Selim.

Geographically, Assiut district has about $28 \%$ of mortality of Bronchopneumonia in the governorate in 2015. Dayrout and Abou Tig come second and third in rank by 16.4 and $12.24 \%$ respectively. El-Ghanaim district comes at last representing 2.12\%. Sahel Selim does not have any mortalities of Bronchopneumonia in 2015. In 2020, ratios change as Assiut district has more than $65 \%$ of mortality of Bronchopneumonia. Next came El-Quseya, Dayrout, Manfalout representing together 21\%. Abnoub comes at last with no more than $0.55 \%$ of mortality of Bronchopneumonia.

About $62 \%$ of mortality of acute bronchitis concentrates in Assiut district in 2015. Assiut district maintains the same percentage of participation during 2020. Abnoub district comes second in rank by about $19 \%$. It records about $29.5 \%$ of mortality of acute bronchitis in the governorate in 2020. 375 cases of respiratory failure are recorded in the districts of Dayrout and Assiut representing about 45\%. 300 cases are recorded in the districts of El-Fatah and El-Quseya. Hence, the four districts together constitute $81 \%$ of mortality of respiratory failure in 2015 . The map has changed in a way that Assiut district solely captures about 51\% of mortality of respiratory failure in the governorate in 2020, while the districts of El-Fatah and Dayrout capture about $21 \%$. 
Tahle 2. Distnhution and Characterizalion of Respiratory Diseases Causes and Mortality Rates in Assiut Governorate in $2015,2020$.

\begin{tabular}{|c|c|c|c|c|c|c|c|c|c|c|c|}
\hline \multirow[b]{3}{*}{ Destrists } & \multicolumn{11}{|c|}{2615} \\
\hline & \multicolumn{11}{|c|}{ Dostrbutic mutes } \\
\hline & $\begin{array}{l}\text { Arreachitis } \\
\text { pactenatis }\end{array}$ & $\begin{array}{c}\text { Asute } \\
\text { brouctials }\end{array}$ & $\begin{array}{l}\text { Chet } \\
\text { aters }\end{array}$ & Asoma & $\begin{array}{c}\text { Lare } \\
\text { nherode"t }\end{array}$ & $\begin{array}{l}\text { Beypinowy } \\
\text { halere }\end{array}$ & $\begin{array}{l}\text { Utaclassificd } \\
\text { Viral } \\
\text { pmaturata }\end{array}$ & 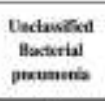 & $\begin{array}{l}\text { Prousenia } \\
\text { carsed by } \\
\text { uailenificd } \\
\text { argativans: }\end{array}$ & $\begin{array}{c}\text { Other } \\
\text { reasoss:-2 }\end{array}$ & Tatal \\
\hline Aneat & 25) & 3911 & 18 & 54 & 85 & 105 & 2 & II & 53 & $2 \hbar$ & IिI \\
\hline Drgoni & 155 & 2 & 28 & 8 & 3 & 193 & 2 & 3 & 9 & 4 & 365 \\
\hline E_Ounes & $\sqrt{3}$ & $\frac{\pi}{4}$ & 17 & 39 & 14 & 143 & 6 & 6 & 0 & 5 & 319 \\
\hline Mntios & 32 & 29 & 2 & 9 & 9 & 47 & 0 & 9 & 43 & 0 & 16 \\
\hline Nenced & 94 & 103 & 6 & $A$ & 3 & 2 & 0 & 6 & 0 & 28 & 230 \\
\hline E_fulh & $\pi$ & 5 & $T$ & 16 & 4 & 157 & 3 & 2 & 0 & 2 & 276 \\
\hline Sold Selom & n & 0 & 9 & $i$ & 1 & $2 x$ & 0 & 6 & $x$ & 2 & 94 \\
\hline E_Holati & 70 & 27 & I & 3 & $T$ & II & 5 & 9 & 3 & 1 & 117 \\
\hline Abse fog & 112 & II & 3 & 18 & $\theta$ & 21 & 0 & 6 & (3) & 11 & $20 \%$ \\
\hline Sath & 55 & 3 & 40 & 0 & 9 & 47 & 0 & 9 & $\theta$ & 0 & 145 \\
\hline EGranin & 20 & 0 & 6 & 0 & $\theta$ & 2 & 6 & 6 & N & 2 & $\$$ \\
\hline Tital & 9E5 & 540 & 125 & 191 & I2I & 833 & 7 & 16 & 223 & 36 & 3061 \\
\hline \multirow[b]{2}{*}{ Dotrints } & \multicolumn{11}{|c|}{ Sfruet Gemerwarati } \\
\hline & $\begin{array}{l}\text { Broectitb } \\
\text { |ptenmata }\end{array}$ & $\begin{array}{c}\text { Acuit } \\
\text { brusctilisis }\end{array}$ & $\begin{array}{l}\text { Ches } \\
\text { atare }\end{array}$ & Aathese & $\begin{array}{l}\text { Lung } \\
\text { Pitmois }\end{array}$ & $\begin{array}{c}\text { Socpiraiken } \\
\text { fulene }\end{array}$ & $\begin{array}{l}\text { Undavedified } \\
\text { Viral } \\
\text { socancola }\end{array}$ & $\begin{array}{l}\text { Enctawilkd } \\
\text { Benterial } \\
\text { pexumeita }\end{array}$ & $\begin{array}{l}\text { Poumatita } \\
\text { catsed by } \\
\text { taibinticd } \\
\text { anganisms }\end{array}$ & $\begin{array}{l}\text { Other } \\
\text { resums }\end{array}$ & Total \\
\hline Masin & 2859 & 0282 & 10.4 & 26.27 & $7 \times 59$ & 2.41 & $235 ?$ & 6ot5 & $25 \pi$ & 4023 & 3435 \\
\hline Degreasi & 1630 & 037 & 224 & 4.39 & 2.48 & 21.61 & 2857 & 18.75 & 0 & 1047 & 1258 \\
\hline EQuns & 1016 & 166 & 116 & 109 & 1157 & 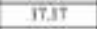 & 0 & 0 & 0 & $5 \times 1$ & 10.2 \\
\hline Menfabex & 35 & 54 & 1.6 & $4 \pi$ & 6 & 5.64 & 0 & 0 & 1028 & 0 & 5.21 \\
\hline Wocen & 5.9 & [8.9] & 48 & 2251 & 2.48 & 624 & 0 & 6 & 0 & 3296 & 789 \\
\hline ELfityh & $78 ?$ & 3.5 & III & $\mathrm{R}, \mathrm{V}$ & $33 t$ & 18.15 & 42.86 & 12.5 & 0 & 2.33 & 96 \\
\hline Shat Sclan & 0 & 0 & 7.2 & 186 & 6,93 & 3.86 & 0 & 9 & 12.35 & 2.33 & 2.42 \\
\hline E Badan & 760 & 6.97 & 118 & 1.97 & 680 & 182 & 0 & 9 & 135 & 1.16 & 3.52 \\
\hline Wre Tig & 1234 & 216 & 2.4 & 9.42 & 6 & 252 & 0 & 6 & 13.45 & 1279 & 6.73 \\
\hline Solta & 601 & 0.55 & 32 & 6 & $\overline{6}$ & 564 & 6 & 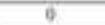 & 0 & in & 4.4 \\
\hline E_Chasin & 2.19 & $\pi$ & 9 & 0 & 9 & 024 & 0 & 6 & 27.8 & 2.33 & 2.81 \\
\hline Total & 106 & 100 & 106 & 160 & 100 & 194 & 160 & 196 & 190 & 100 & 160 \\
\hline \multirow[b]{2}{*}{ Destints } & \multicolumn{11}{|c|}{ F frue Detrial } \\
\hline & $\begin{array}{l}\text { Arrartitis } \\
\text { peremenin }\end{array}$ & $\begin{array}{c}\text { Acuite } \\
\text { braschitis }\end{array}$ & $\begin{array}{l}\text { Chest } \\
\text { alsons }\end{array}$ & Nothne & $\begin{array}{l}\text { Lure } \\
\text { ehronis }\end{array}$ & $\begin{array}{l}\text { Reyenom } \\
\text { falure and }\end{array}$ & $\begin{array}{l}\text { Uisclasifiad } \\
\text { Viral } \\
\text { pouanuma }\end{array}$ & 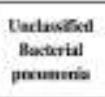 & 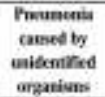 & $\begin{array}{l}\text { Othrm } \\
\text { renents }\end{array}$ & Total \\
\hline Assaz & 2645 & 32.95 & $1.7 \pi$ & 5.14 & 704 & 18.55 & 678 & IIS & 504 & $2 A ?$ & 60 \\
\hline Degwai & $3 \times 56$ & 052 & 7.27 & 200 & 6.7. & 4675 & 62 & 2.75 & 0 & 2.34 & 100 \\
\hline E_Quser & 2015 & $2 \mathrm{~K}_{2}$ & 5.3 & 11.91 & +3 & 4.83 & 0 & e & 0 & 157 & 160 \\
\hline Mnifikes & 1975 & 179 & 1.23 & 556 & 0 & 2901 & 0 & $\theta$ & 20.94 & 0 & 100 \\
\hline Niscech & 2250 & \$3.1 & 251 & 1390 & 1.26 & 0.84 & 0 & 6 & 0 & 11.52 & 100 \\
\hline EFwh & 26000 & 6.88 & 035 & $5 x$ & 1.45 & 5688 & 108 & 6,72 & 0 & 072 & 100 \\
\hline Shat Selon & 0 & II & 12.16 & 27 & 135 & 37.94 & 0 & 9 & 4824 & 25 & 100 \\
\hline EHalari & 5963 & 2306 & 635 & 256 & 0.85 & 5.4 & 0 & 6 & 258 & 11.85 & 160 \\
\hline Nhos Tog & 9437 & 5.4 & in & $\mathrm{k}, 4$ & 6 & 1039 & 6 & 6 & 1456 & 5.34 & 100 \\
\hline Sala & 37.53 & $26 \pi$ & 2759 & 0 & 0 & $32+1$ & 0 & 0 & 0 & 0 & 100 \\
\hline EGhain & 2326 & iI & 9 & 0 & 9 & 2.33 & 0 & 9 & $\pi 20$ & 2.33 & 100 \\
\hline Tutal & 29.9 & 15,75 & 4.01 & 624 & 3.95 & 27.22 & 0.2 & 452 & 7.9 & 2.81 & 160 \\
\hline \multirow[b]{2}{*}{ Destricts } & \multicolumn{11}{|c|}{ Mnetality raiviow penen } \\
\hline & $\begin{array}{l}\text { Ervarbitis } \\
\text { pertumusia }\end{array}$ & $\begin{array}{c}\text { Acule } \\
\text { branctitis }\end{array}$ & $\begin{array}{l}\text { Chest } \\
\text { aleres }\end{array}$ & Aathas & $\begin{array}{l}\text { Laty } \\
\text { filmovis }\end{array}$ & $\begin{array}{l}\text { Boypiaboy } \\
\text { fahure and }\end{array}$ & $\begin{array}{l}\text { Uoxtasdifint } \\
\text { Yiral } \\
\text { govurscala }\end{array}$ & $\begin{array}{l}\text { tadasibed } \\
\text { Bonterial } \\
\text { poxumente }\end{array}$ & 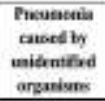 & $\begin{array}{l}\text { Othor } \\
\text { raven }\end{array}$ & Tatal \\
\hline Assix & $2 \pi 2$ & 3.46 & 2.18 & 055 & की? & 109 & $0 \times 0$ & o.11 & 054 & $0 x$ & 1071 \\
\hline Deroual & 26 & 0103 & $6 .+3$ & Q1t & क्S & 3.12 & 0.52 & $8 \pi 5$ & 0 & 0.16 & 6.67 \\
\hline ELones & $2 \pi$ & 02 & 931 & 085 & $03 t$ & 318 & 0 & 0 & 0 & 0.11 & 71 \\
\hline Mnishes & $6 n^{2}$ & 0.56 & 624 & a.1T & 0 & Q9 & 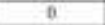 & 6 & $8 \times 3$ & 0 & 3,12 \\
\hline Abaceb & LAt & 260 & 9.10 & 1.12 & 600 & 818 & 6 & 6 & 0 & 0.73 & 6.25 \\
\hline EFfish & 237 & 0.63 & sal & 0.53 & 0.13 & 5.17 & 0.1 & का & 0 & 09 ? & 9.6 \\
\hline Stwet Selien & 0 & 0 & est & a12 & 0,05 & 167 & 0 & 0 & 1.9i & 0.12 & 4.41 \\
\hline E. Batan & 2.61 & 101 & 604 & a.1 & e04 & $0 \times 1$ & 6 & 6 & 0.11 & 604 & 436 \\
\hline Wose $T$; & $3 \% 9$ & 0.33 & ses & 0.55 & 6 & $0 \times 4$ & D & 6 & 0.91 & 0.33 & 6.24 \\
\hline Salth & 291 & 016 & 2.12 & 6 & 0 & $20 y$ & 0 & 6 & 0 & 0 & 7,9 \\
\hline E_Qrimin & ISI & II & 9 & 0 & 6 & 2.15 & 6 & 6 & $4(-f)$ & 0.15 & i.S. \\
\hline Total & 2.13 & $1.2 x$ & 0.20 & $0+4$ & $6.3 x$ & 204 & 6.61 & 6.94 & 4.52 & 0.2 & 7.12 \\
\hline
\end{tabular}

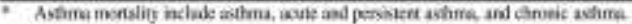

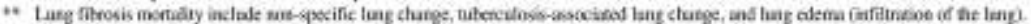

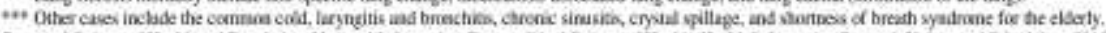

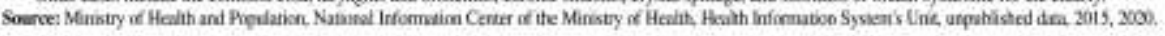


Table 2. Follow.

\begin{tabular}{|c|c|c|c|c|c|c|c|c|c|c|c|c|}
\hline \multirow[b]{3}{*}{ Ditrikes } & \multicolumn{12}{|c|}{2010} \\
\hline & \multicolumn{12}{|c|}{ Detetriats munhin } \\
\hline & $\begin{array}{l}\text { Erreachion } \\
\text { peremsain }\end{array}$ & $\begin{array}{c}\text { Arate } \\
\text { brooshith }\end{array}$ & $\begin{array}{l}\text { Ched } \\
\text { atergy }\end{array}$ & Ashanz & $\begin{array}{l}\text { lane } \\
\text { fitrodt }\end{array}$ & $\begin{array}{l}\text { Riyinaten } \\
\text { fallare }\end{array}$ & $\begin{array}{l}\text { Undiswified } \\
\text { Vinal } \\
\text { panamata }\end{array}$ & $\begin{array}{l}\text { Cadessifked } \\
\text { llacienial } \\
\text { preaneria }\end{array}$ & $\begin{array}{l}\text { Panususia } \\
\text { caused by } \\
\text { unidentined } \\
\text { srgations }\end{array}$ & $\begin{array}{l}\text { Nord } \\
\text { caruea } \\
\text { siras }\end{array}$ & $\begin{array}{l}\text { Other } \\
\text { resers }\end{array}$ & Tued \\
\hline Anviai & 1261 & 156 & 5 & 26 & (6) & 685 & 131 & 51 & ii & 151 & 70 & 2400 \\
\hline Deynd & 117 & 5 & 6 & 5 & 3 & 113 & 2 & 41 & 0 & 1 & 16 & 310 \\
\hline ELQuseyz & 181 & I & 6 & 8 & 2 & III & 15 & 3 & 0 & 0 & $y$ & III \\
\hline Mtiriaber & in & 10 & 5 & 2 & 5 & 52 & 0 & 0 & 0 & 6 & in & 158 \\
\hline Anew & 10 & 73 & D & 16 & 5 & 2 & 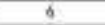 & 0 & I & 6 & 1 & 100 \\
\hline Elfant & is & $I$ & 0 & $\mathrm{I}$ & 6 & IS8 & 3 & 0 & 0 & 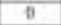 & 1 & 213 \\
\hline stelselin & 0 & 6 & 6 & 0 & 0 & 21 & 0 & 6 & $\pi$ & 1 & 0 & 33 \\
\hline El posian & $\pi$ & 2 & 0 & 2 & 6 & 38 & 12 & 3 & 9 & 10 & 0 & 130 \\
\hline Ahen Ty & 43 & $\theta$ & 1 & 36 & 0 & H & 0 & D & 0 & 158 & 0 & 345 \\
\hline Sodfi. & 30 & 0 & D & 0 & 0 & 91 & 0 & D & ig & D & 0 & 81 \\
\hline ELGtmin & 47 & 9 & 0 & il & $\theta$ & 11 & 0 & 0 & 0 & 0 & II & 47 \\
\hline Total & 146 & 345 & 23 & 36 & 168 & 1242 & 253 & 166 & 23 & 353 & 4 & 4315 \\
\hline \multirow[b]{2}{*}{ Nitrikts } & \multicolumn{12}{|c|}{5 frue Gercherait } \\
\hline & & $\begin{array}{c}\text { Acste } \\
\text { truachits }\end{array}$ & $\begin{array}{l}\text { Setsibisi } \\
\text { ty is the } \\
\text { deet }\end{array}$ & $\begin{array}{l}\text { Asttree } \\
\text { cass }\end{array}$ & $\begin{array}{l}\text { Lane } \\
\text { fitrocis }\end{array}$ & $\begin{array}{l}\text { Megpiniten } \\
\text { failare }\end{array}$ & $\begin{array}{c}\text { Unclavified } \\
\text { Vind } \\
\text { pocumeis }\end{array}$ & 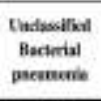 & 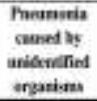 & $\begin{array}{l}\text { Novid } \\
\text { carcea } \\
\text { viras }\end{array}$ & $\begin{array}{l}\text { Otter } \\
\text { minsesa }\end{array}$ & Teed \\
\hline Asiai & 66.27 & 6268 & 21.74 & 3021 & 9537 & 5097 & 82.65 & 4157 & 47.53 & 4536 & 95 & 595 \\
\hline Desnat & $6 \%$ & 201 & 360 & 638 & 2.8 & 9.1 & 691 & 45.21 & 9 & 025 & 29 & 3.18 \\
\hline ELQuicga & 10 & 04 & $2 t i m$ & [RS? & 1.85 & $x 37$ & 6.85 & $2.8 t$ & 0 & 0 & 25 & T(A) \\
\hline Murfibes & 484 & 402 & 23.74 & 2.63 & 0 & 419 & 0 & D & 0 & 0 & 0 & 300 \\
\hline Arovol & 054 & 202 & 0 & 2105 & 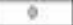 & 0.16 & 2,74 & 0 & 435. & 0 & 25 & 253 \\
\hline Elfin & $2 \mathrm{fil}$ & 0.8 & 0 & 1.32 & 5 & $12 n 2$ & in & 0 & 0 & 0 & 2.5 & 4.93 \\
\hline Stelsctin & 0 & 6 & D & 0 & 6 & 160 & a & 0 & 42.2 & 025 & 0 & 6.76 \\
\hline El Batani & 386 & a.8 & 0 & 263 & 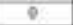 & 161 & 9.75 & 200 & $\theta$ & 254 & (I) & 278 \\
\hline thou Te & $2 \mathrm{~s}$ & 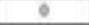 & 435 & 2109 & 9 & 709 & 0 & 0 & 0 & 9218 & 0 & in \\
\hline Socka & 163 & 6 & 0 & 0 & 8 & 411 & 9 & 0 & (0) & 0 & 0 & 1.88 \\
\hline Elchanin & 253 & 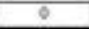 & 0 & 0 & 8 & 0 & 0 & 0 & 0 & 0 & 0 & IIII \\
\hline Total & 101 & 106 & 160 & 199 & 116 & 160 & 19 & 160 & 190 & 160 & 100 & 19 \\
\hline \multirow[b]{2}{*}{ Distrikts } & \multicolumn{12}{|c|}{5 fras Bistric } \\
\hline & $\begin{array}{l}\text { Bneaditibs } \\
\text { proumaib }\end{array}$ & $\begin{array}{c}\text { Acts } \\
\text { hreachith }\end{array}$ & $\begin{array}{l}\text { Cheat } \\
\text { ateres }\end{array}$ & Astanes & $\begin{array}{l}\text { Lang } \\
\text { forred }\end{array}$ & $\begin{array}{c}\text { Reyintany } \\
\text { failary }\end{array}$ & $\begin{array}{c}\text { Indawefled } \\
\text { Vint } \\
\text { pustanitia }\end{array}$ & $\begin{array}{l}\text { Codasilhed } \\
\text { Decietal } \\
\text { parancial }\end{array}$ & 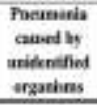 & $\begin{array}{l}\text { Nowet } \\
\text { concea } \\
\text { sirus }\end{array}$ & $\begin{array}{l}\text { Other } \\
\text { nements }\end{array}$ & Treal \\
\hline Msiai & 4675 & $6 \%$ & a.16 & tili & 401 & 2454 & 305 & 1.56 & 8.43 & 7.12 & 0.74 & 10 \\
\hline Deyrcal & 35.44 & 1.01 & 1.94 & 101 & as? & Ho. & 000 & 15,05 & $\theta$ & 0.32 & 325 & 100 \\
\hline Elonses & 55.2 & 03 & 1.81 & 241 & an & 31.33 & 452 & 69 & 0 & 6 & 271 & 109 \\
\hline Maffike & 56.13 & $6: 3$ & 316 & 127 & 6 & 1291 & 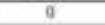 & 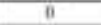 & 0 & 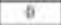 & iI & 101 \\
\hline Nowen & 9.17 & BOT & 0 & 1451 & 8 & 163 & 5.5 & 0 & 692 & 8 & 0,42 & 100 \\
\hline Eufal & 27.54 & 64 & 0 & 0.67 & 8 & 9618 & 1.41 & 0 & 0 & 0 & a4f & 100 \\
\hline Sebelsetn & 0 & 6 & D & 0 & 5 & 6364 & 0 & 0 & 33.33 & 305 & 0 & 100 \\
\hline El_Bulan & 99.5 & 1.28 & 0 & 167 & 6 & 16,07 & III & 25 & 0 & 833 & D & 108 \\
\hline Ahow Te & 12.40 & $\theta$ & 039 & $4 \Omega_{2}$ & 9 & $25, A$ & 0 & 0 & $\theta$ & $5)$.3 & II & 101 \\
\hline Sulfa & 37.4 & 0 & 6 & 0 & 9 & 52.96 & 0 & $\overline{0}$ & 0 & 0 & 0 & 100 \\
\hline El_cimin & 10 & 6 & D & 0 & 6 & II & d & D & 0 & D & II & 100 \\
\hline Tatal & 4.4.4 & $s, \pi$ & 0.50 & 1.76 & 25 & 25.76 & $\operatorname{sen}$ & 26 & 8.53 & 3.1 & Q59 & 190 \\
\hline \multirow[b]{2}{*}{ Niturkts } & \multicolumn{12}{|c|}{ Mertalicy ratilitee promes } \\
\hline & $\begin{array}{l}\text { Frreachiss } \\
\text { pectereata }\end{array}$ & $\begin{array}{c}\text { Acrete } \\
\text { bruathits }\end{array}$ & $\begin{array}{l}\text { Chet } \\
\text { aferny }\end{array}$ & Astane & $\begin{array}{l}\text { lang } \\
\text { manots }\end{array}$ & $\begin{array}{l}\text { Respinatery } \\
\text { nillare }\end{array}$ & $\begin{array}{l}\text { Unciruifiad } \\
\text { Viral } \\
\text { pormanis }\end{array}$ & $\begin{array}{l}\text { Codasified } \\
\text { Bacterial } \\
\text { pseameria }\end{array}$ & $\begin{array}{l}\text { Pananania } \\
\text { caused by } \\
\text { unidereifiod } \\
\text { spgations }\end{array}$ & $\begin{array}{l}\text { Sosed } \\
\text { ounts } \\
\text { vins }\end{array}$ & $\begin{array}{l}\text { Othar } \\
\text { remenes }\end{array}$ & Tied \\
\hline Msiat & 1155 & 1.5 & 0.6 & 625 & 293 & 600 & 1.74 & 04 & s.11 & 1.76 & 0.18 & $24 \pi$ \\
\hline Deymet & 187 & 089 & 0.1 & ens & 000 & 18 & ONB & in & 0 & 002 & 016 & 494 \\
\hline EL Quseys & 3.0 & 002 & in & 0.16 & 604 & 2.13 & QMI & 066 & 0 & 0 & 0.16 & 6.79 \\
\hline Mafike & 161 & e.15 & 046 & $\operatorname{den}$ & 6 & 0.44 & 6 & $\overline{0}$ & 0 & 0 & 0 & 2.80 \\
\hline Nonen & 023 & 168 & 0 & 0.97 & 0 & 006 & 0.14 & 0 & $\$ \pi$ & 0 & 0 we & 25 \\
\hline Elrma & 14 & bas & D & $6 \pi{ }^{2}$ & $\theta$ & 499 & 80.9 & 0 & 0 & 0 & 00 & $\$ 14$ \\
\hline Satel Setn & 0 & 0 & 0 & 0 & 0 & 1.1 & 0 & 0 & 0.5. & 005 & 0 & 1.73 \\
\hline EL Busari & 200 & 009 & 0 & an? & 6 & 0.7 & 0.2 & (111 & 0 & 035 & iI & 421 \\
\hline Now To & $1 \sqrt{1}$ & 8 & 000 & $6 A 7$ & 6 & 258 & 9 & 0 & (0) & 5.11 & DI & 1815 \\
\hline Selh & 156 & 6 & 0 & il & 8 & 204 & 9 & 0 & 0 & 0 & II & 22 \\
\hline E Gomin & 132 & 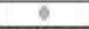 & 0 & 0 & 9 & i & 0 & 0 & 0 & 6 & 0 & 332 \\
\hline Tatal & 19 & 6.54 & 0.65 & 8.16 & 6.23 & 268 & A.A & 023 & 8.05 & 0.5 & Q6n & 9.31 \\
\hline
\end{tabular}




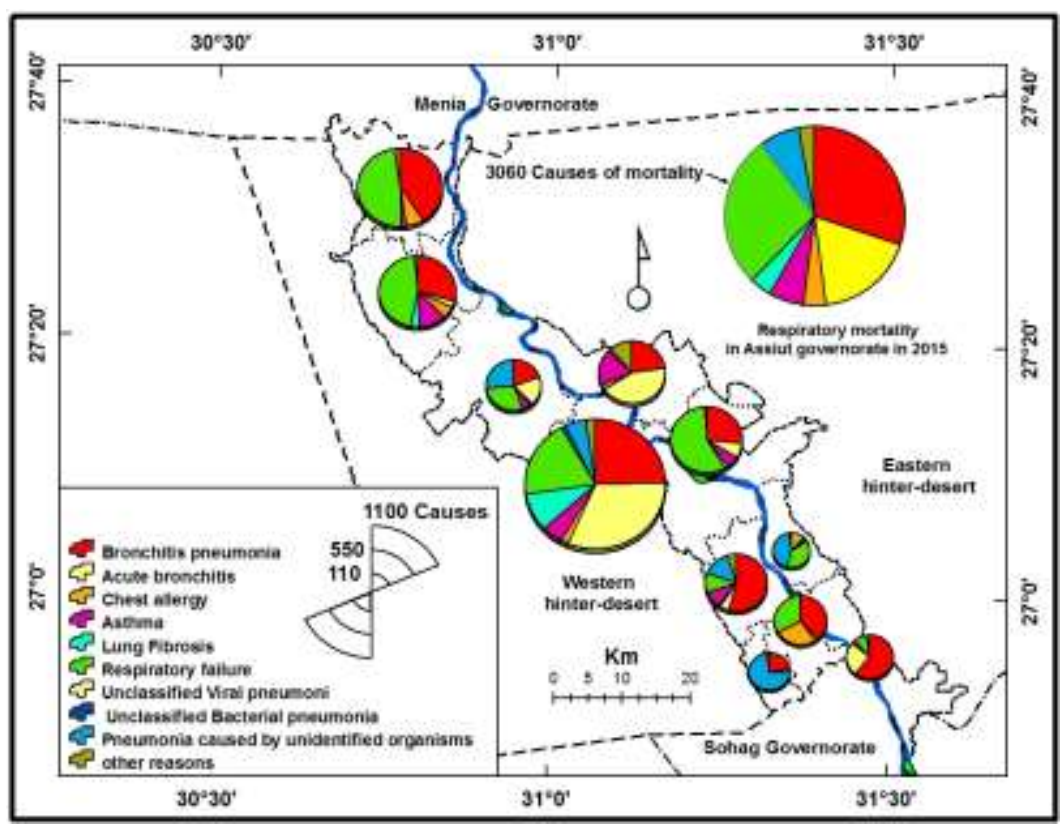

Figure 3. Distribution of Mortality of Respiratory Diseases in Assiut governorate in 2015.

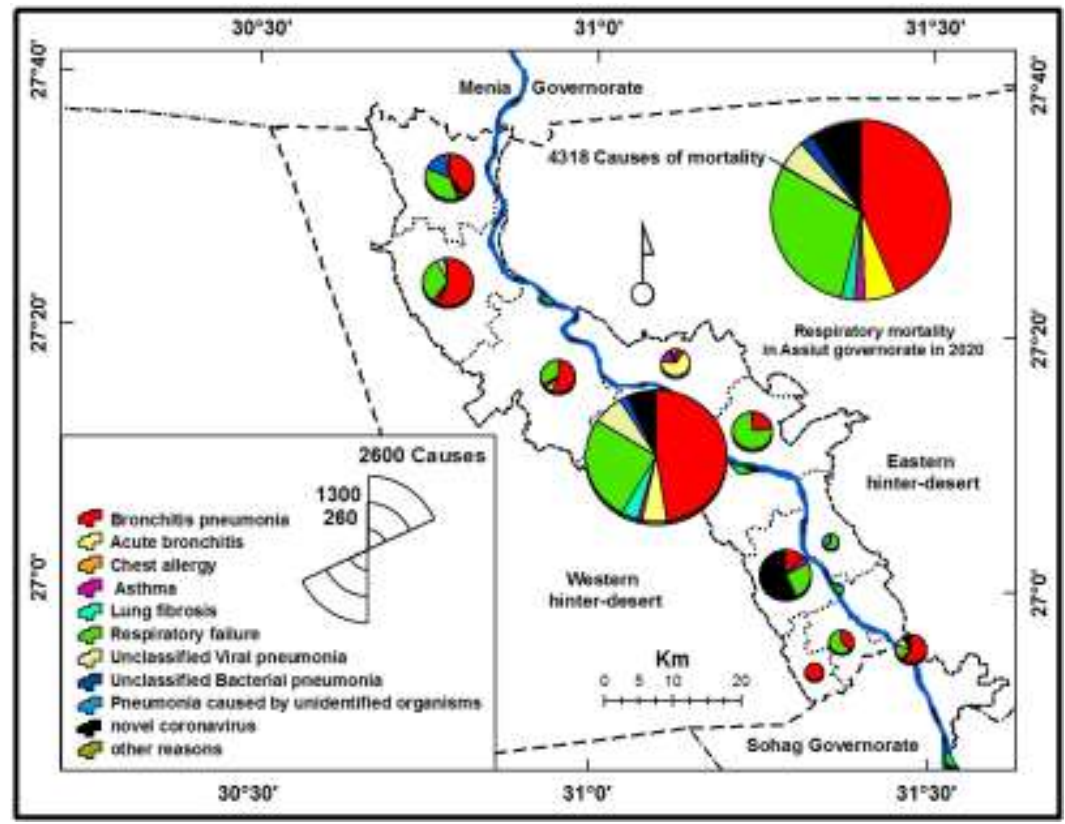

Figure 4. Distribution of Mortality of Respiratory Diseases in Assiut Governorate in 2020. 
During 2020, Sadfa has about 40 fatalities of chest allergy representing $32 \%$. Dayrout, on the other hand, has $22 \%$ of mortality of allergy. Thus, more than $54 \%$ of mortality of allergy concentrates in these two districts. During 2020, the districts of; Assiut, Dayrout, El-Quseya, and Manfalout share nearly by about $95 \%$ of mortality of allergy in the governorate. Abou Tig has one case of the 23 ones recorded in the governorate. The other districts do not have any mortalities of chest allergy during 2020.

The districts of; Assiut, Abnoub and El-Quseya come first, capturing $71 \%$ of mortality of asthma in the governorate in 2015. The share of Assiut district rises, capturing along with Abnoub and Abou Tig about $76.2 \%$ of mortality of asthma in 2020. Assiut district possesses about $78.5 \%$ of mortality of lung fibrosis in 2015. El-Quseya comes second by $11.5 \%$. The map changes that Assiut district captures more than $95 \%$ of lung fibrosis by 103 fatalities out of 108 in the governorate in 2020.

Cases of unclassified viral pneumonia, which are 7 in 2015, distribute as 3 are in El-Fatah while both Assiut district and Dayrout share the remaining 4. Mortality of unclassified viral pneumonia rises in 2020 to become 2019 cases. 82.6\% of them concentrate in Assiut district. 12\% of mortality is recorded in El-Quseya and El-Badari. The share of Assiut district in mortality of unclassified bacterial pneumonia during 2015 is about $68.75 \%$ which is 11 cases out of the 16 cases in the governorate. Together, Assiut district and Dayrout have about 99 fatalities in 2020 which is $94.5 \%$ of the total mortality rate of unclassified bacterial pneumonia in the governorate. El-Ghanaim comes first in mortality of pneumonia resulting from unidentified organisms. It has 62 deaths by $27.8 \%$. Together with Assiut district, El-Ghanaim possesses about more than half of the cases in the governorate in 2015. Fatality cases in the governorate drops to become 23 cases in 2020. That number is distributed among Assiut district, Sahel Selim in addition to one case recorded in Abnoub.

According to the relative sharing of mortality among the districts of the governorate, it is evident that Bronchopneumonia shares by about $30 \%$ of the total rate of mortality in the governorate. It shares by about $60 \%$ in ElBadari and 50\% in Abou Tig. Its share is not more than $20 \%$ of fatalities in Manfalout in 2015. Bronchopneumonia's participation in fatality rates rises in 2020 to be $42.6 \%$ of the total number of fatalities in the governorate. Therefore, all fatalities of respiratory diseases concentrates in El-Ghanaim, sharing by more than $50 \%$ of fatalities of El-Badari, El-Quseya, and Manfalout. They share the least in Abnoub where they record only $10 \%$ of the total number of fatalities. 
Respiratory failure shares by about $27.22 \%$ of mortality burden in 2015 . Its highest participation exceeds $56 \%$ of the total mortality rate in El-Fatah. Yet, it does not go beyond 1\% of mortality in Abnoub in 2015 where it shares by $1.83 \%$ of mortality rate in 2020 being the least participation at all. Respiratory failure achieves its highest participation in El-Fatah, Sahel Selim and Sadfa by not less than $62 \%$ of its mortality even at its least rates, in these 3 districts. Respiratory failure does not participate by any share in ElGhanaim during 2020.

Cases of acute bronchitis carry the burden of $43 \%$ of mortality of respiratory diseases in Abnoub. Its participation does not go beyond 3\% of the total fatalities in Dayrout, El-Quseya and Sadfa. It does not record any fatalities both in Sahel Selim and in El-Ghanaim during 2015. Its highest participation is in Abnoub in 2020 as it records $67 \%$ of mortality. Yet, it does not share by more than $7 \%$ in the rest of the districts due to the general decrease of its participation in mortality. It only records $5.77 \%$ of the total rate of mortality in all the districts of the governorate.

Pneumonia resulting of unidentified organisms shares by $7.3 \%$ of mortality in the governorate in 2015. It shares the most in El-Ghanaim by $72 \%$ of mortality of respiratory disease. It is also the reason of mortality of more than $43 \%$ in Sahel Selim. Again, it is the reason of mortality of more than fourth of mortalities in Manfalout. Five districts do not record any mortalities of this reason in 2015. Participation of this kind of pneumonia as a cause of mortality decreases in general in 2020 . The governorate has only 23 cases of mortality which is not more than $0.55 \%$. Its highest participation by about $33 \%$ of mortality rate is in Sahel Selim. No cases are found in eight districts of the governorate in 2020 .

Asthma shares by $6.4 \%$ of mortality rate in the governorate in 2015 . It has its highest participation in Abnoub by $18 \%$ of the total fatalities in the district which recorded $22.5 \%$ of mortality in the governorate. In 2020, participation of asthma does not go beyond $1.8 \%$ of the total mortalities in the governorate. It records its lowest share in Sadfa with no more than $0.5 \%$ while it keeps hitting the highest participation in Abnoub by $15 \%$ of mortality rate of respiratory diseases in that district.

Chest allergy records about $4 \%$ of mortality of respiratory diseases in the governorate. It carries the burden of $27.5 \%$ of mortality in Sadfa district. It has its least participation both in El-Fatah and in El-Badari by less than $1 \%$. No fatalities are recoded at all by this reason in El-Ghanaim in 2015. Participation of chest allergy drops in 2020 as 6 districts record not even one mortality. Its highest participation is in Manfalout by $3.16 \%$ of mortality burden of respiratory diseases in the district. 
Lung fibrosis has its highest participation in Assiut district during 2015 by $9 \%$ of mortality burden. Districts of Manfalout, Sadfa and El-Ghanaim do not have any fatalities of this cause. The number of districts that do not record any mortalities because of lung fibrosis increases in 2020 as all districts, except for of El-Quseya and Dayrout in addition to Assiut district in which cases of lung fibrosis are $4 \%$ of the district mortality rate, have no mortalities. Viral pneumonia and unclassified bacterial pneumonia do not record noticeable participation in 2015. Their rates rise during 2020 as viral pneumonia represents $5 \%$ of mortality burden in the governorate. It records its highest participation by $10 \%$ of mortality in El-Badari. Bacterial pneumonia records its highest participation by $15.5 \%$ of mortality rate in Dayrout. Corona virus shares by about $9.1 \%$ of mortality burden in the governorate. Its highest participation was by about $7.3 \%$ of mortality burden in Abou Tig district.

Concerning mortality rate of respiratory diseases in the governorate and the change in its spatial map, it is found that the general rate reaches 7.12/ 10000 persons during 2015. Assiut district reports the highest rate by more than 10/10000 persons. The least rates are recorded in Manfalout with no more than 4/ 10000 persons. El-Fatah has a mortality rate of 9/10000 persons. The rate varies between 6:8/ 10000 persons in the districts of Dayrout, El-Quseya, Abnoub, Abou Tig, Sadfa and El-Ghanaim during 2015. This map encounters an obvious change during 2020. The general rate in the governorate rises to $9 / 10000$ persons, and to $24 / 10000$ persons in Assiut district. Abou Tig comes next by $10 / 10000$ persons. The rate, on the other hand, drops in Abnoub, Sahel Selim, El-Ghanaim in addition to Manfalout, as it does not go beyond 4 / 10000 persons.

The general rate of mortality of bronchopneumonia reaches $2.13 / 10000$ persons. It has its highest rate in Abou Tig with more than 3/ 10000 persons. That same rate does not exceed 2/10000 in Abnoub, El-Ghanaim, and Manfalout which achieves the highest rate in the governorate in 2015. The general rate of mortality rises to be close to 4/ 10000 persons during 2020. It reaches its maximum in Assiut district by about 11.5/ 10000 persons. Abnoub district records the least rate of mortality of bronchopneumonia.

Assiut district has the highest rate of mortality of acute bronchitis in the governorate during 2016 by about 3.5/ 10000 persons. Abnoub district comes second by about 2.5/ 10000 persons. Except for El-Badari district which has a rate of $1 / 10000$ persons, the rate does not go in the other districts beyond $0.65 /$ 10000 persons. In general, the rate of mortality of acute bronchitis drops during 2020 reaching $0.54 / 10000$ persons as it does not, even in its highest rate which is in Abnoub, goes beyond 1.68/10000 persons. 
The maximum rate of mortality of chest allergy in 2015 is recorded in Sadfa with more than $2 / 10000$ persons. This rate does not go beyond $0.55 / 10000$ persons in the other districts of the governorate. The rate of mortality of chest allergy decreases in 2020 as it does not exceed $0.15 / 10000$ persons in its highest rate in El-Quseya. Asthma has its highest rate in 2015, in Abnoub by about $1.12 / 10000$ persons. The rates decrease in all the districts during 2020 to reach its highest in Abou Tig by 0.47/ 10000 persons. Mortality of lung fibrosis does not go, in its highest rate in Assiut district, beyond 1/10000 persons both during 2015 and 2020.

The general rate of respiratory failure reaches $1.94 / 10000$ persons during 2015. It has its highest rate in El-Fatah by about 5.17/10000 persons. The rate goes beyond 6/10000 persons in Assiut district being the highest rate all over the governorate.

Rates of unclassified viral pneumonia have low rates in 2015. It is found only in three districts. Its highest rate in El-Fatah is not more than $0.1 / 10000$ persons. Its rate rises in 2020 reaching a climax in Assiut district by $1.67 / 10000$ persons. After recording low rate during 2015, mortality of viral pneumonia rises to its maximum during 2020 in Dayrout by about 0.8/10000 persons.

On the contrary, rate of mortality of pneumonia of unidentified organisms witnesses a decrease during 2020. Its general rates in 2015 reaches about $0.52 / 10000$ persons as El-Ghanaim experiences its highest rate by about $4.69 / 10000$ persons. Its mortality rate is close to $2 / 10000$ persons in Sahel Selim. During 2020, pneumonia resulting of unidentified organisms does not record more than $0.05 / 10000$ persons. Its highest rate during 2020 , does not go, in the three districts that have fatalities of this kind of pneumonia; Sahel Selim, Assiut district and Abnoub, beyond 0.58/10000 persons which is the rate in Sahel Selim.

The general rate of mortality of other respiratory diseases reaches $0.2 / 10000$ persons. The rate rises to go beyond this number in the districts of Abnoub, Abou Tig and Assiut which has a rate of 0.73/10000 persons. The other districts of the governorate have even lower rates. Some districts do not even record any fatalities of these other respiratory diseases during 2015. During 2020, the general rate of mortality of other respiratory diseases do not go beyond 0.09/10000 persons. Their highest rates are in Assiut district and El-Quseya by about $0.18 / 10000$ persons. They have even lower rates in Dayrout, Abnoub, and El-Fatah. Manfalout, Sahel Selim, El-Badari, Sadfa and El-Ghanaim do not record any fatalities of this reason. 


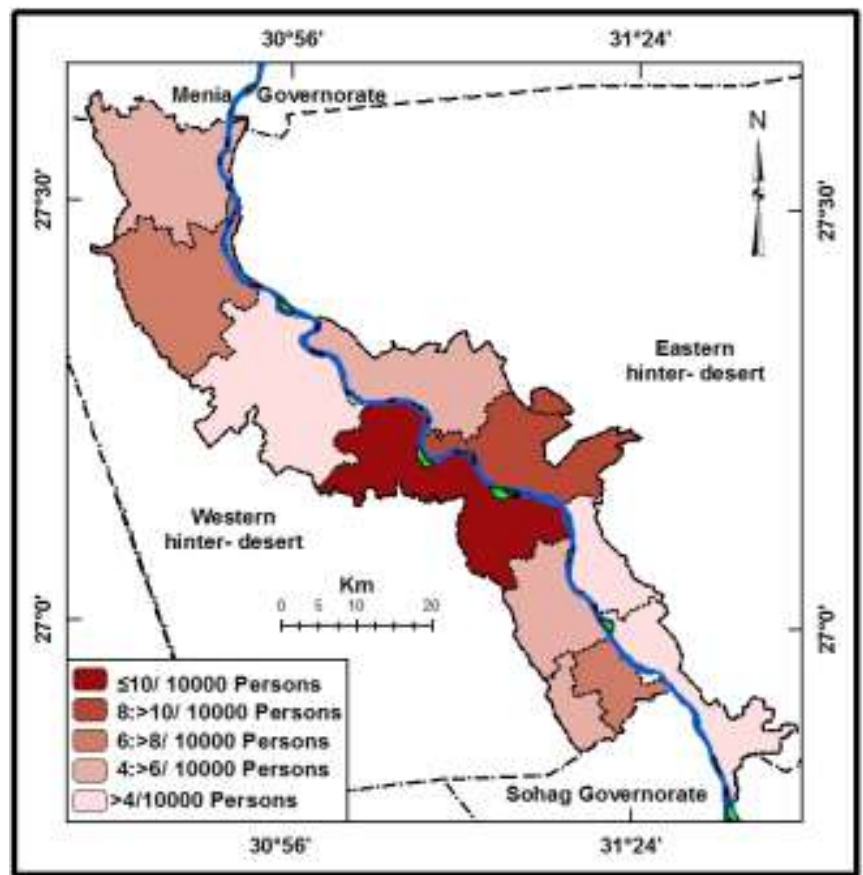

Figure 5. Mortality Rates of Respiratory Diseases in Assiut Governorate in 2015.

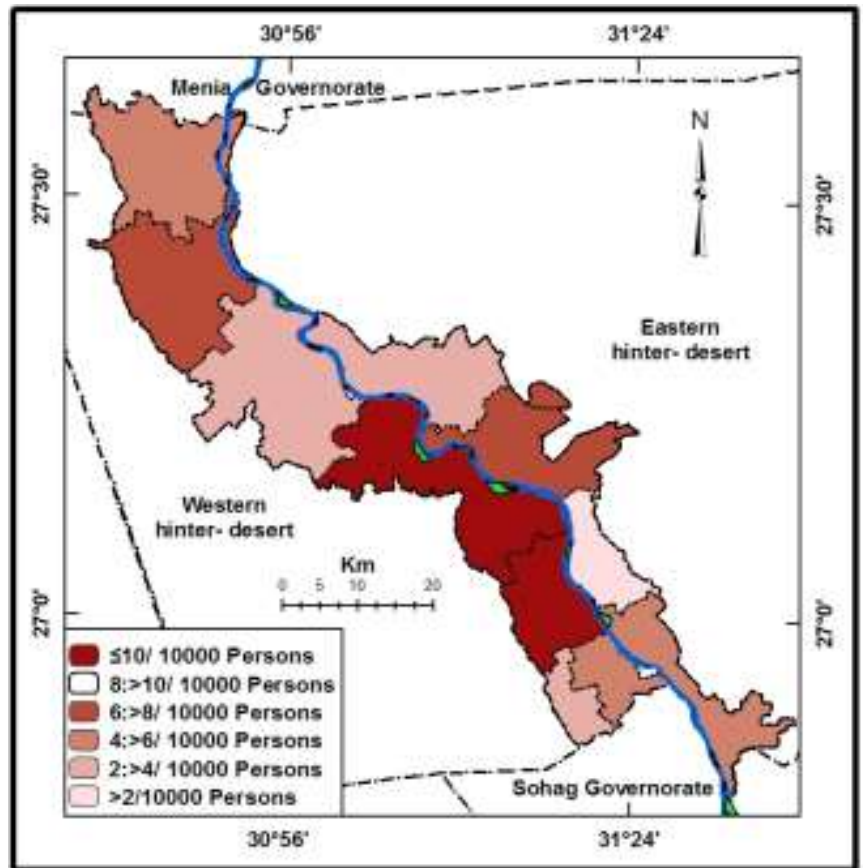

Figure 6. Mortality Rates of Respiratory Diseases in Assiut Governorate in 2020. 
The general rate of mortality of novel corona virus reaches about $0.85 / 10000$ persons during 2020. Abou Tig has the highest rate of mortality by corona by about $5.8 / 10000$ persons. The rate goes down in El-Badari as it does not exceed 0.4/10000 persons. Very low rates show up in Sahel Selim and Dayrout which record only 2 fatalities over 2020.

\section{Third: Time variance of mortality of respiratory diseases in Assiut governorate.}

(1) Analyzing the coefficient of seasonal change of mortality of respiratory diseases:

Both of table 3 and the time analysis of mortality of respiratory diseases in Assiut governorate from 2015-2020 indicate that the number of fatalities of respiratory diseases fluctuates over the months of the year. Mortalities reach a climax in January, the month which has about 2148 mortalities, during the years from $2015-2020$, representing $11.61 \%$ of the 165525 cases of mortality of respiratory diseases in the governorate. June and December come second and third by 10.74 and $10.17 \%$ respectively. September is the month that has the least mortalities of respiratory diseases during the studied period. October, over these years, has 1083 mortalities, which is about 5.85\% of the total number of mortalities of respiratory diseases in the governorate ${ }^{(1)}$.

Concerning the seasons of the year and the seasonality of mortality, months of winter come first in the number of mortalities of respiratory diseases as they have 5825 cases which represent $31.47 \%$ of the total mortalities in the governorate. January comes first among the months of winter. Months of summer come second recording 5147 cases representing $27.06 \%$. June comes first among the months of summer. During spring, 3979 died representing $21.5 \%$ of mortality of respiratory diseases. March witnesses the highest rate of mortality among the months of spring. Autumn is the season that witnesses the least mortalities of respiratory diseases representing $19.22 \%$ of the total number of mortalities. October is the month that has the least mortalities, as it is the least dangerous month being climatically suitable for the patients of respiratory diseases of the studied area.

Calculating the coefficient of seasonal change of mortality of respiratory diseases in Assiut governorate indicates that January comes first recording the highest number of mortalities by a coefficient of $139.26 \%$. It is followed by June and December by a coefficient of change of $128.82 \%$ and $122.08 \%$ respectively. Number of mortalities decreases the most in October

(1) The coefficient of seasonality is calculated by the average of calling cases in each month of the year divided by the general average of the months of the year, given that each month, in average, equals 100 and a year equals 1200 . The outcome is multiplied by 100 . Thus, the coefficient of seasonality varies either by being higher or lower than a 100 . 
by a coefficient of seasonal change of $72.87 \%$. April is the third least month concerning the number of mortalities of respiratory diseases even though it belongs to the season of spring.

Analyzing the coefficient of seasonality during the months of the years from 2015-2020 reveals that the highest seasonality coefficient of January is in 2016 as it records $186.7 \%$. It has its least seasonality coefficient during the years 2018 and 2020 not recording more than 124\%. June has its highest seasonality coefficient in 2020. Its seasonal change coefficient is higher than these of the rest of the other months in 2020. It even surpasses January and comes first regarding the number of mortalities in 2020 by a seasonal change coefficient of 234.5\%. It records its lowest coefficient during 2016, as it does not go beyond $82 \%$. Again, July surpasses January by recording its highest seasonality coefficient in 2020 by $191 \%$. It records its lowest seasonality coefficient in 2015 by not more than $76 \%$. Except for July 2020, seasonality coefficient of July does not go beyond $100 \%$ during the studied period.

Seasonality coefficient of December reaches its maximum in 2016 by about $165.5 \%$. It hits its lowest in 2020 by $77.5 \%$ given that its seasonality coefficient does not go beyond $122 \%$ during that era. This is not due to a drop in the number of mortalities of respiratory diseases in December of that year but to their concentration in June and July, which witness the peak of Covid 19 in the governorate. February has its highest seasonality coefficient in 2015 as it reaches $141.57 \%$. It comes second after January leaving December behind concerning the mortalities of respiratory diseases. It has its least seasonality coefficient in 2020 representing $94.77 \%$. October records its least seasonality coefficient in 2020 by about $55.58 \%$ and hits its highest rate in 2018 by $90 \%$. November, on the other hand, records its least seasonality coefficient by $55 \%$ in 2020 , the year in which it also has the least coefficient among all months. That is the case even though its seasonality coefficient does not go less than 91\% during the period from 2015-2019.

After analyzing the seasonality coefficient, it's evident that up to 2019, mortality of respiratory diseases concentrates more in the months of December, January and February. Their distributional pattern differs in 2020. In the studied era, the least number of mortalities of respiratory diseases, 141, is recorded in October 2016. Up to the end of 2019, the highest number of mortalities of respiratory diseases is recorded in January 2015. By 2020, June records the highest number by about 876 mortalities even though its previous highest number was 245 in 2015 . Therefore, the difference between the month that witnesses the highest numbers and that witnesses the lowest numbers is about 735 mortalities. The monthly average of mortality of respiratory diseases in Assiut governorate is about 257 mortalities during 72 months of the era from January 2015- December 2020. 


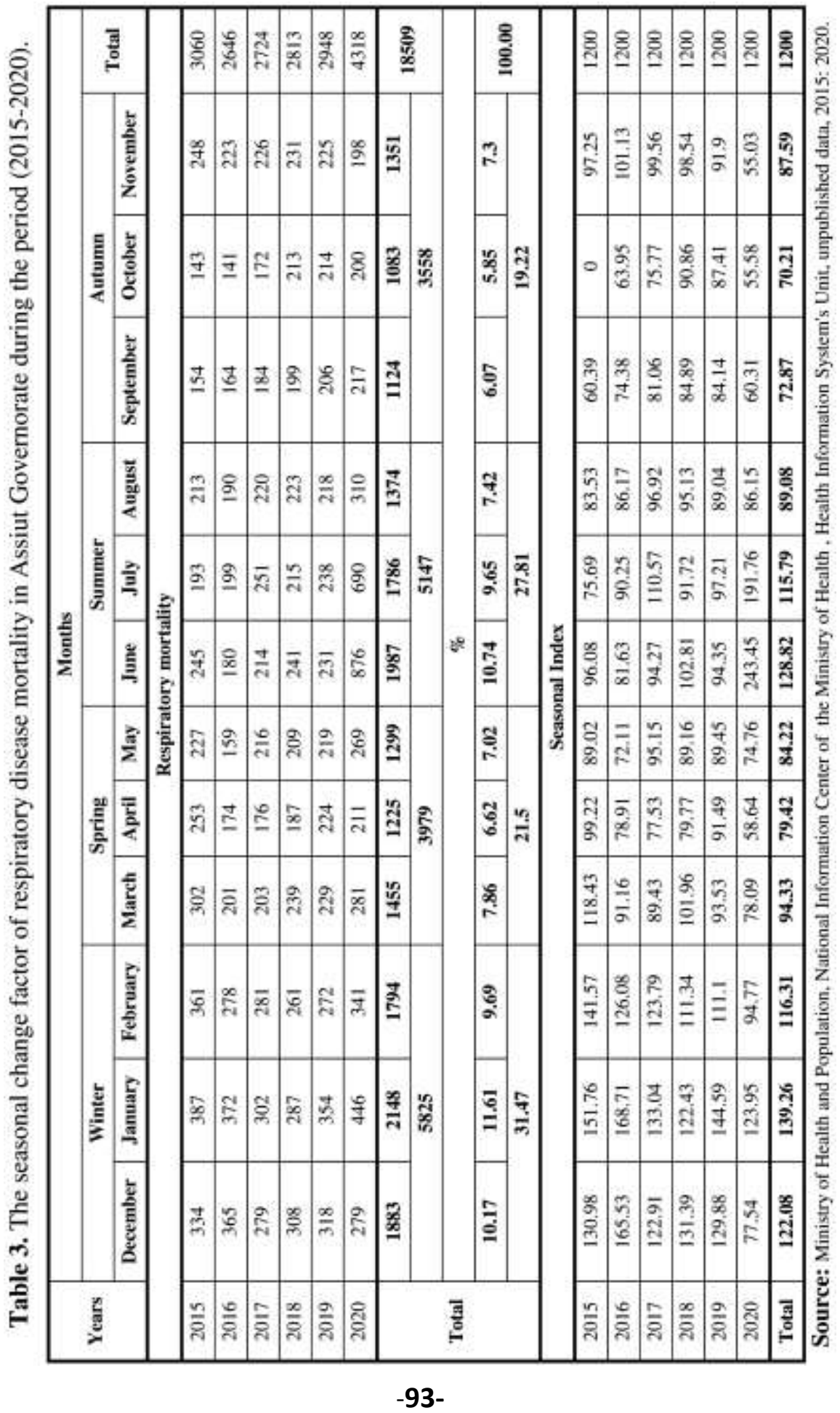




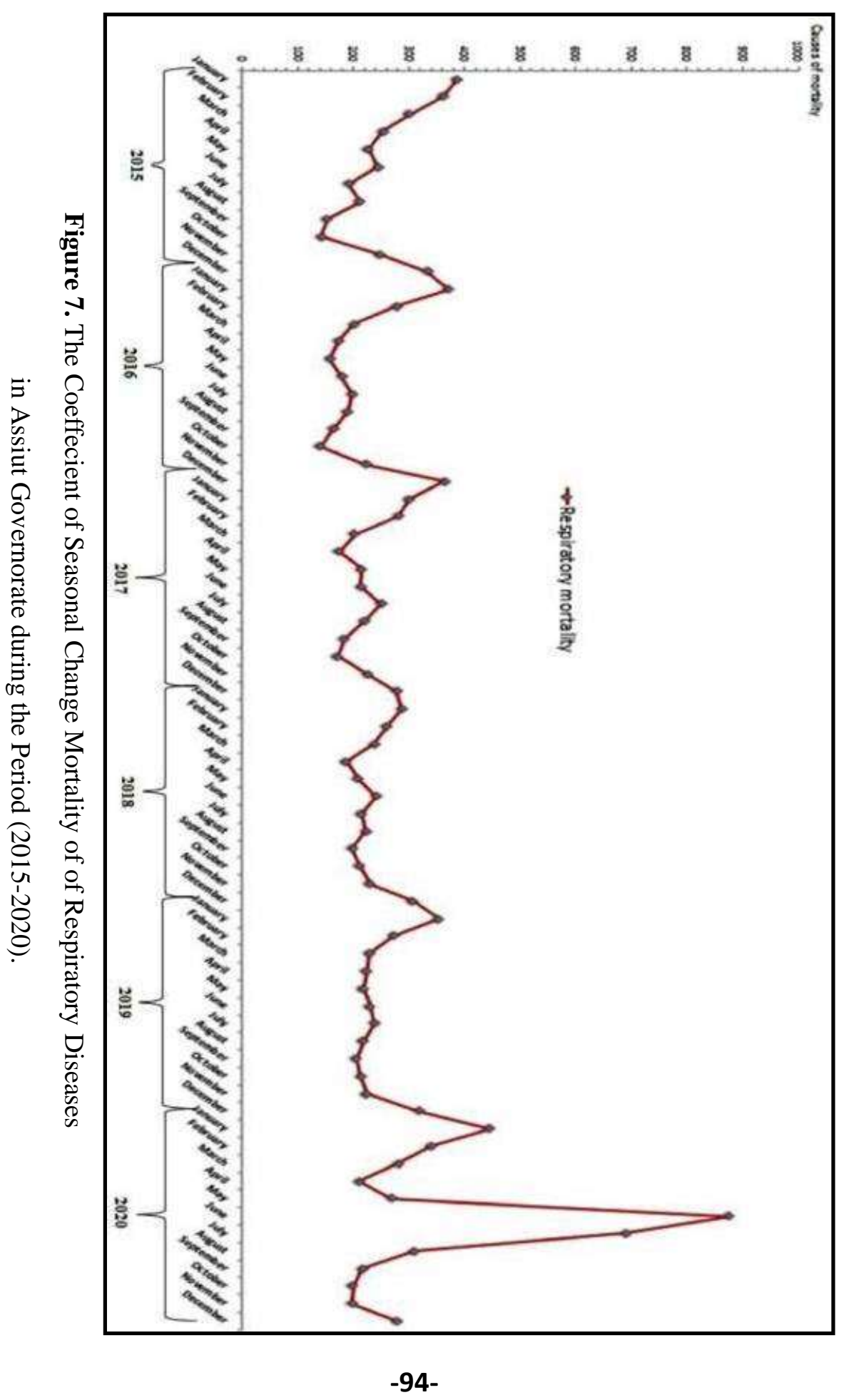




\section{(2) Distribution of mortality of respiratory diseases over the districts of the governorate over the different months of the year:}

Table (4) indicates that June comes first in the number of mortalities of respiratory diseases that reaches 876 in 2020. Thus, June carries fifth of the burden of mortalities of respiratory diseases in the governorate. July comes next by about $16 \%$ of the mortalities in the governorate. September and October record less than 400 mortalities by not more than $9.5 \%$ of mortality of respiratory diseases in the governorate.

Assiut district possesses more than half of the mortalities of respiratory diseases in the governorate over the whole year. That is the case even though it has only $22.5 \%$ of the population of the governorate. Its share of mortalities in the governorate rises during June as it records 615 death cases representing $70.2 \%$ of the total mortalities in the governorate which was 876 cases in that month. It also has the least percentage of mortalities during January and February by no more than $53 \%$ of the total mortalities of respiratory diseases in the governorate.

Dayrout has shared by $7.18 \%$ of mortalities of respiratory diseases in the governorate. It hits its highest during February and October by more than $11 \%$ of mortalities in the governorate. It has the least mortalities during June, July and September by not less than 5\% of mortalities in the governorate. El-Quseya has its highest participation during May by about $10.78 \%$. It has its least participation in mortalities of respiratory diseases during September and January by about 4.15 and $4.93 \%$ respectively. The highest number of mortalities in Manfalout is recorded during August and November by more than $6 \%$ of the total mortalities in the governorate. Yet, Manfalout has its least participation during March by no more than $1 \%$ of mortalities of respiratory diseases in the governorate.

Abnoub has its highest participation during January by about $6 \%$ of mortalities of the governorate. Its least participation is in July and August by less than $1 \%$ of mortalities of respiratory diseases in the governorate. The highest participation of El-Fatah is during April and December by $8.06 \%$ and $7.17 \%$ of the mortalities of the governorate respectively. Sahel Selim records its highest percentage during May and January by about 4.46 and $3.14 \%$. It has less mortality during February, April, and June. It does not record any fatalities of respiratory diseases during the rest of the months of the year. El-Badari participates the most in April by 5.2\% while its participation during June and December do not go beyond $1.5 \%$ of mortalities in the governorate. 


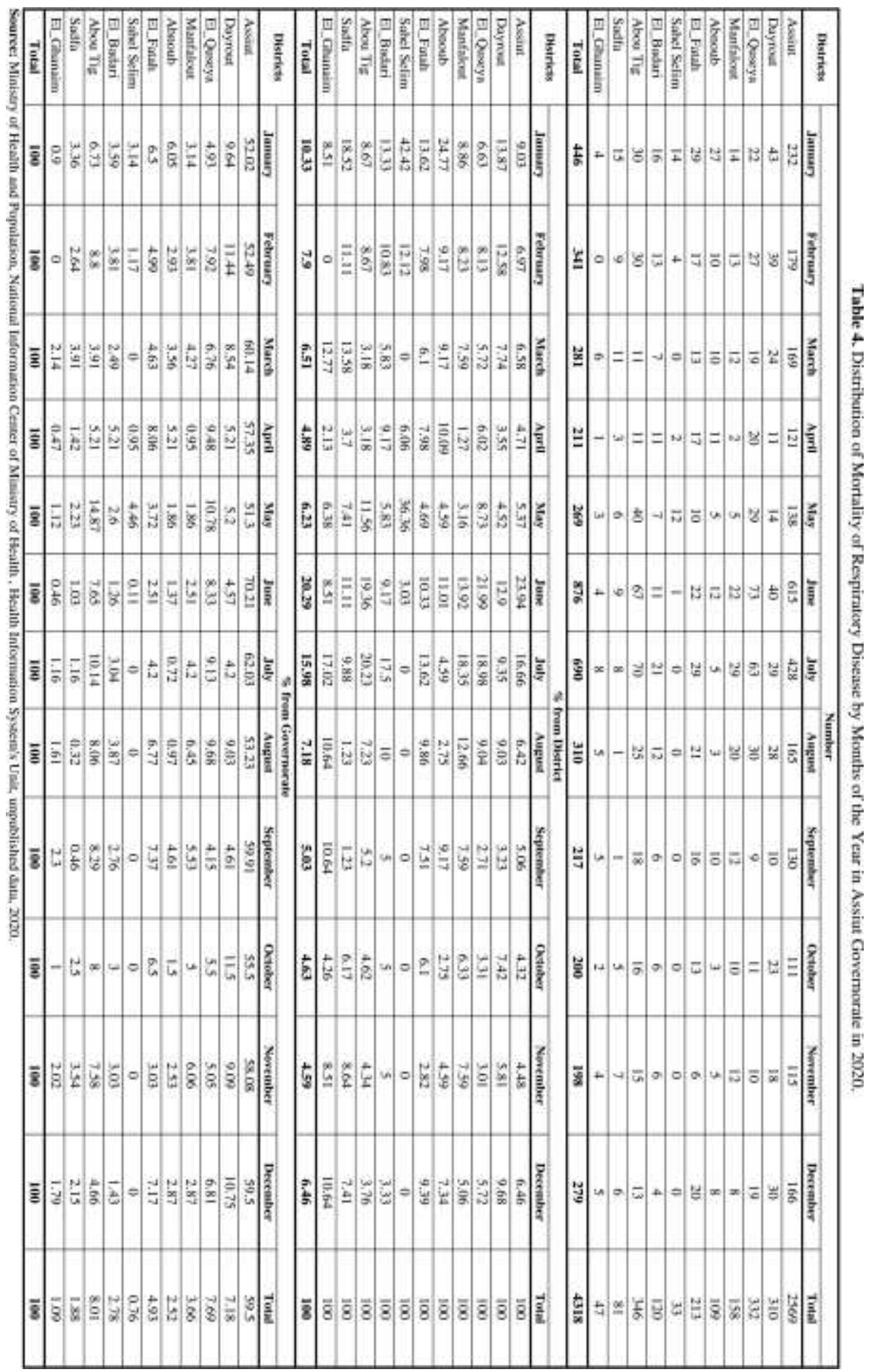




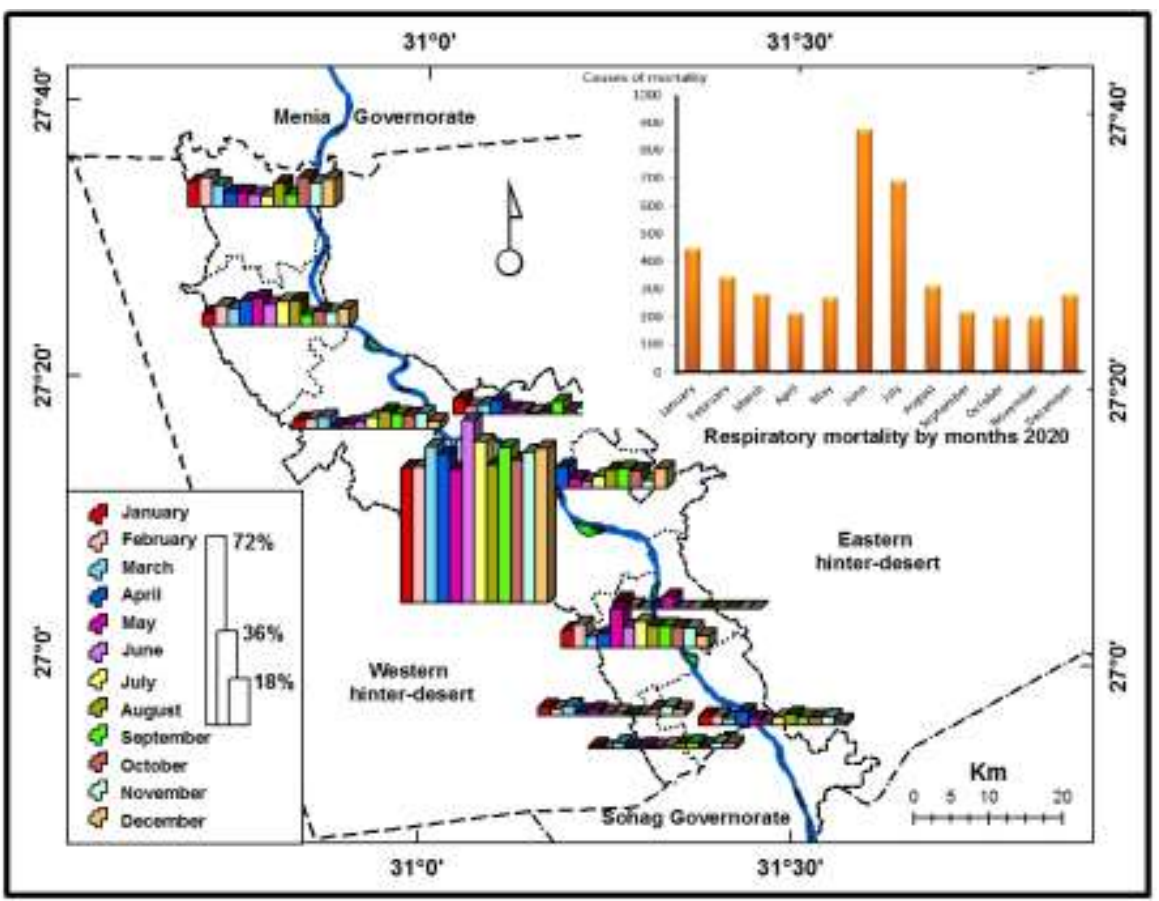

Figure 8. Distribution of Mortality of Respiratory Diseases by Months in Assiut governorate in 2020.

Abou Tig has its highest participation during May by about $15 \%$ of mortalities of respiratory diseases in the governorate. It comes second after Assiut district. It records its least participation during March by not more than $4 \%$ of mortalities of the governorate. The highest participation of Sadfa is in March and November by more than 3.5\%. It achieves its least participation during August and September by no more than $0.5 \%$ of mortalities of the governorate. El-Ghanaim shares by more than $2 \%$ of mortalities of the governorate. That is its highest share during March, September and November. Its least participation does not go beyond $0.5 \%$ during April and June. El-Ghanaim has no mortalities of respiratory diseases during February.

The percentages of mortalities vary over the months of the year in the governorate. July carries the burden of $20 \%$ of mortality of respiratory diseases. It records its highest participation in Assiut district as 24\% passed away during that month in the district. Its least participation is in Sahel Selim by about $3 \%$ of mortalities of the district. July has its highest participation in Abou Tig by about $20.3 \%$ of mortalities in the district. In 
July, more than $18 \%$ of mortalities of El-Quseya and Manfalout is recorded. The least participation is in Abnoub by about $4.6 \%$.

January records its highest share, among the rest of the months, in Sahel Selim by about $42.4 \%$. In Abnoub, January has $25 \%$ of mortalities of the district; its least share is in El-Quseya by no more than $7 \%$ of mortalities of the district. The participation of February varies between $12 \%$ as its highest share in Dayrout and Sahel Selim and less than 7\% in Assiut district. October does not share by more than $8 \%$ in all the districts of the governorate. Its highest participation is in Dayrout by $7.4 \%$ while its least participation is in Abnoub by about $2.75 \%$. All in all, the highest percentage of participation, over the year and at all districts, is recorded in June in Assiut district. The share of that month is about $24 \%$ of mortalities of respiratory diseases in Assiut district. The least percentages of participation at all are recorded in Manfalout which has $1.72 \%$ of mortalities of respiratory diseases.

\section{Fourth: Age structure of mortality by respiratory diseases.}

Analyzing the data of age structure of mortality of respiratory diseases, as given in table (5), shows a change in the distributional map among the different age groups. The rates of mortality among the youngest; younger than 1 year, nearly equals the rates of mortality among the oldest, over 65 during 2015 by $33.79 \%$ of infants and of $34.38 \%$ among the eldest. The distributional map changes during 2020 as about $43 \%$ concentrated among the age group of 65 years old and older. The rates of mortality among infants less than 1 year old which records $20.29 \%$ nearly equals the rates of mortality among the age group from 50-65 years old which represents $19.89 \%$ of all mortalities of respiratory diseases.

The age group from 1-15 years old witnesses a decrease in its mortality rates of respiratory diseases as it goes down from $9.18 \%$ in 2015 to $5.93 \%$ in 2020. Again, mortalities of the age group from 5-15 years old decreas from 2.65 to $2.04 \%$ in 2020 . Mortalities among the age group from $15-50$ years old escalates to be $9.59 \%$ in 2020 after being $6.37 \%$ of the total mortalities in 2015. In the light of the previous information, it is possible to conclude that in general all age groups less than 15 years old witness a noticeable fall as they decrease from $45.62 \%$ of mortality of respiratory diseases in 2015 to $27.62 \%$ in 2020 . On the other hand, mortality of respiratory diseases rises in all age groups above 15 years old as it records in 2020 about $72.37 \%$. This is not due to the fall in numbers of mortalities among age groups less than 15 years old but because of the increase in mortalities among the age groups above 15 years old as they are the most mobile groups in society and hence 
are more exposed to infectious respiratory diseases. The case is so also as the age group over 65 years old is the least capable of tolerating diseases.

Concerning the change in spatial aspect of mortality of respiratory diseases and their age groups, it is evident that the age group of 65 years old witnesses a noticeable rise in certain districts of the governorate in contrast to its decrease in other districts. $54.55 \%$ of mortality in Sahel Selim belongs to this age group in 2020. That percentage is $36.49 \%$ in 2015 . The percentage rises from 23.41 to 46.59 in Assiut district. Mortality of the age group of 65 years old rises, from 37.66 to $44.04 \%$ in Abnoub, from 38.41 to $48.83 \%$ in El-Fatah and from 17.09 to $20 \%$ in El-Badari. Its mortality rate resembles $45.66 \%$ of the total mortalities in Abou Tig after it had been 30.1\% in 2015 . On the contrary, Dayrout, El-Quseya, Manfalout, Sadfa and El-Ghanaim witness a drop in the percentage of mortalities in the age group of 65 years old. The most decrease is in Sadfa where numbers among this age group goes from $51 \%$ in 2015 to $3.7 \%$ in 2020.

Although there is a general decrease in the rate of mortality among infants in 2020, it witnesses a rise in certain districts specially Sadfa and ElGhanaim where rates rise from $27.59 \%$ and $39.53 \%$ in 2015 to $76.54 \%$ and $59.57 \%$ respectively in 2020. Yet, the rates drop in the districts of Assiut and Abou Tig from 39.58 to $13.94 \%$ and from 44.17 to $18.21 \%$ respectively.

The age group from 50-65 years old witnesses a rise in its participation in Manfalout, Dayrout, El_Badari in addition to Assiut district, Sahel Selim and AbuTeij. The participation by this age group in the mortality of respiratory diseases exceeds $22 \%$ in the last 3 districts. Previously in 2015 it wasn't more than $16 \%$. On the contrary, the rates of mortality in this age group decrease in El-Quseya, Abnoub, El-Fatah, Sadfa and El-Ghanaim. Sadfa has the most obvious decrease as numbers go down from $9.66 \%$ in 2015 to $2.47 \%$ in 2020 . This age group do not record any mortality of respiratory diseases in El-Ghanaim.

The age group of 15-50 years old witnesses an escalation in its rate of mortality in all the districts except for Sahel Selim where it drops from 6.76 to $3.03 \%$ and for Sadfa where it goes down from 4.83 to $2.47 \%$ in 2020 . This age group witnesses a slight drop in its participation in all the districts except for Dayrout, Manfalout, Sahel Selim and El-Ghanaim where it slightly rises. The most rise in its participation is in Sahel Selim as it goes up from $1.35 \%$ in 2015 to $3.03 \%$ in 2020 . The age group of $1-5$ years old witnesses a drop in its participation in all districts except for Sadfa where it goes up from $4.14 \%$ in 2015 to $12.35 \%$ in 2020, and El-Ghanaim where it goes up from $12.35 \%$ in 2015 to $19.15 \%$ in 2020 . 


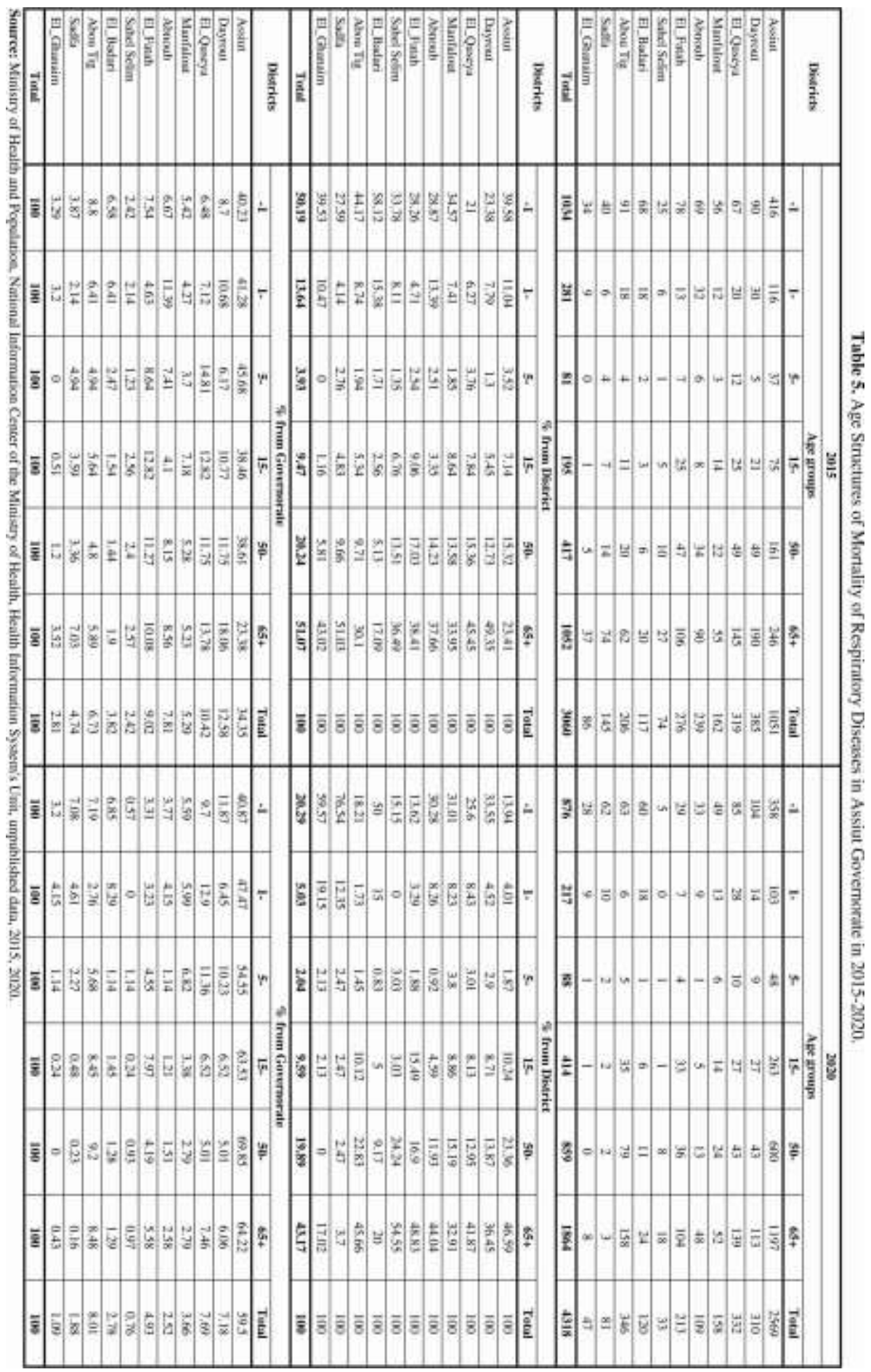




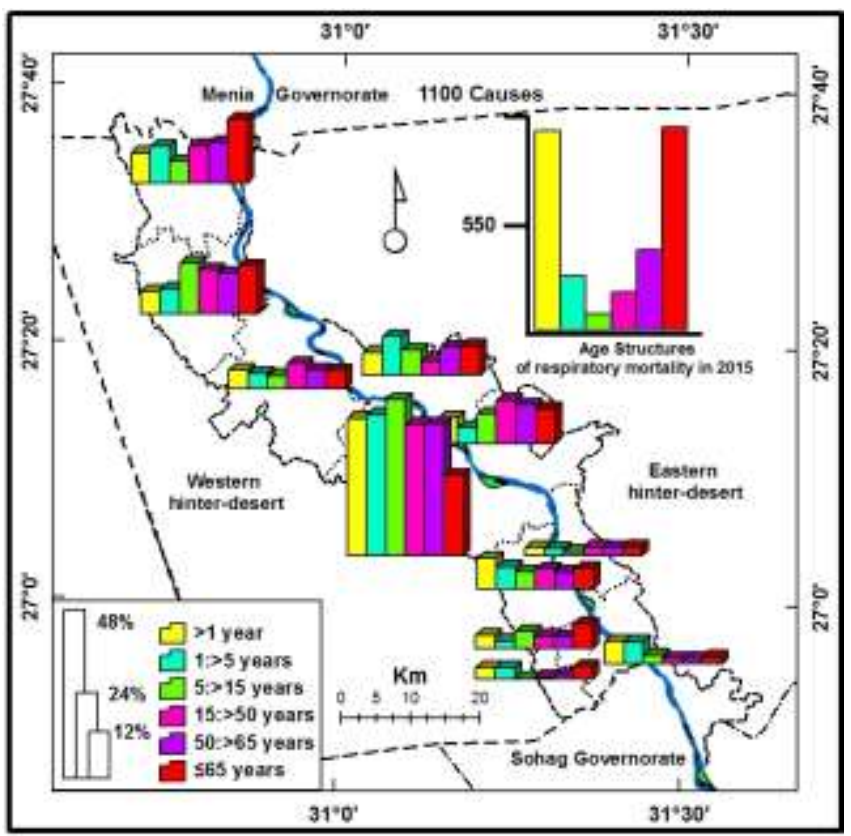

Figure 9. Age Structure of Mortality of Respiratory Diseases in Assiut Governorate in 2015.

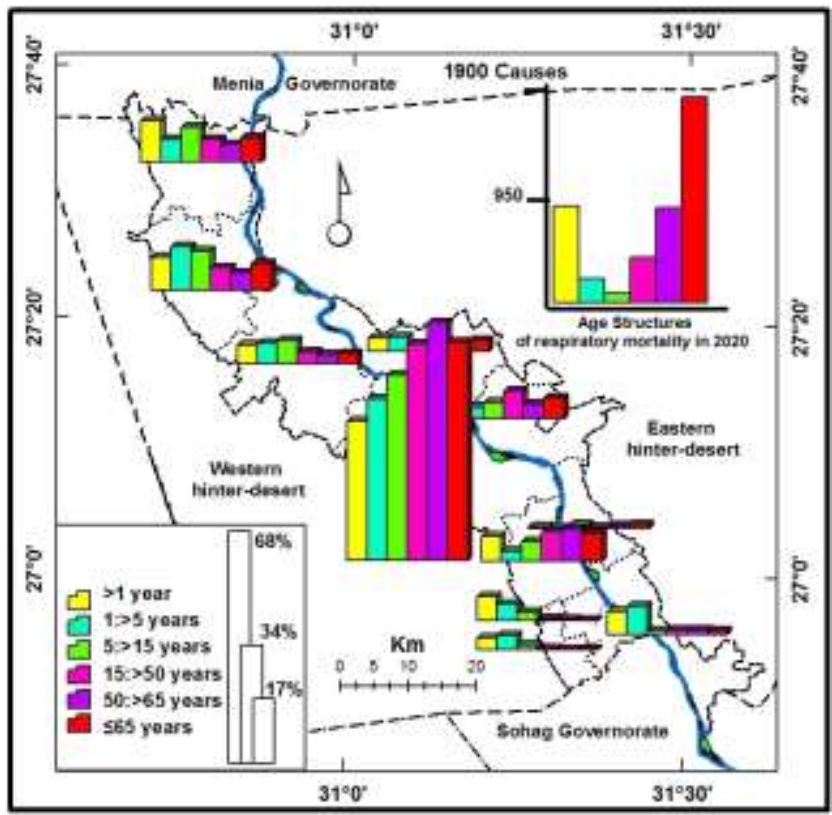

Figure 10. Age Structure Mortality of Respiratory Diseases in Assiut Governorate in 2020. 
Concerning the rates of participation of the different age groups in mortality and their change, it is simply concluded that the group of infants records its highest rates in El-Badari by about $58 \%$ in 2015. It records its highest participation in 2020 in Sadfa by about $76.5 \%$ of mortalities in the district. The highest participation of the age group of above 65 years old is in Sadfa by about $51 \%$ of mortalities in 2015. Sahel Selim replaces Sadfa in 2020 as mortality rates of this age group records $54.55 \%$. The age group from 50-65 years old has its highest participation in El-Fatah in 2015 by about $17 \%$ of mortalities in the district. It records about $24 \%$ of mortalities in Sahel Selim by about $24 \%$ in 2020 . The age group from $15-50$ years old has its highest participation in mortality of respiratory diseases in El-Fatah during 2015 and 2020. It records its highest participation in 2020 by about $15 \%$ of the total mortalities in the district.

According to the distributional map, Assiut district captures $34.35 \%$ of mortalities of respiratory diseases in 2015. Its rate rises to about $60 \%$ of mortalities in the governorate in 2020. Assiut district has its highest participation in mortalities of the age group of 5-15 years old as it has $45 \%$ of the mortalities of this age group in the governorate in 2015. The least rate recorded in Assiut district is among the age group of 65 years old in 2015 as it shares by $23.38 \%$ of mortalities of the governorate. Assiut district has its highest participation in the mortalities of the age group of 50-65 years old and of 65 years old as it shares by more than $64 \%$ of mortalities in the governorate among both of these groups. Dayrout records its highest share in 2015 among the age group of 65 years and above as it shares by $18 \%$ of mortalities among this age group in the governorate. It records its lowest participation during 2020 by $5.01 \%$ of the mortalities of the age group of 5065 years old in the governorate. El-Quseya records its highest rate by $14.8 \%$ of the fatalities among the age group from 5-15 years old in 2015. It records its lowest rate by $5.01 \%$ of mortalities among the age group 50-65 years old in 2020. Manfalout records its highest participation in the mortalities among the age group from 15-50 years old in 2015. Yet, it records its least participation among the age group of 50 years and above by $2.79 \%$. Abnoub has its highest participation in the mortalities of the age group of 1-5 years old in 2015 by $11.4 \%$. Its highest participation in 2020 does not go beyond $4.15 \%$ of the mortalities among the same age group. El-Fatah has $12.82 \%$ of the mortalities of the age group of 15-50 years old as its highest share in 2015. The participation of the other districts of the governorate does not go beyond $9 \%$ in any age group. The highest participation is in Abou Tig which records in 2015 about $8.8 \%$ of mortalities of infants. 


\section{Conclusion}

- The study shows that respiratory diseases carry the burden of mortality of 4318 cases in 2020 in contrast to 3600 cases in 2015 in Assiut governorate. This increase is by about 1258 cases, which is $41.43 \%$ of mortality of respiratory diseases.

- The study highlights a change in the distributional map of fatalities of respiratory diseases in Assiut governorate. Assiut district participation in the total rate of mortality of respiratory diseases rises. It carries the burden of about $60 \%$ of mortality in 2020. Yet, the district's participation does not exceed $35 \%$ of mortality in 2015. Except for Abou Tig which witnesses a rise in its participation, all the other districts of the governorate witness a decrease in their participation in mortality of respiratory diseases in 2020 .

- The study describes a change in the distributional map of mortality of respiratory diseases. The participation of bronchopneumonia, for example, rises noticeably to form $42.6 \%$ and thus becomes the first reason of mortality of respiratory diseases during 2020. Participation of Respiratory failure also rises forming $28.76 \%$. Participation of viral pneumonia escalates to be $5 \%$ and so does bacterial pneumonia. This is in addition to the appearance of novel corona virus whose mortality records about $9 \%$ of death burden in the governorate.

- The study indicates a decrease in the participation of certain reasons in mortality burden. Acute bronchitis participation drops to be $5.8 \%$ in 2020 , while it shares by $17.75 \%$ in 2015 . Participation by chest allergy, Asthma, Lung fibrosis, and pneumonia resulting of unidentified organisms in death burden drops in 2020.

- Out of the study, it is concluded that certain causes of mortality concentrate in certain districts more than others. $65 \%$ of mortality of bronchopneumonia is recorded in Assiut district. Dayrout comes second by about $6.4 \%$. Both Assiut district and Abnoub capture about $92 \%$ of acute bronchitis. Assiut district along with Dayrout, El-Quseya and Manfalout record more than $95 \%$ of mortality of chest allergy. Assiut district, Abnoub and Abou Tig have about $76 \%$ of mortality of asthma. Assiut district, alone, captures about $95.3 \%$ of mortality of lung fibrosis in the governorate. Assiut district came first in mortality of respiratory failure as it carried the burden of the half of its mortality rate. Assiut district, in addition to El-Quseya had about $90 \%$ of mortality of bacterial pneumonia in Assiut governorate. Assiut district and Sahel Selim share by $95.75 \%$ of mortality of pneumonia resulting of unidentified organisms.

- The study indicates that mortality of novel corona virus in Assiut governorate reaches 393 cases representing $9 \%$ of mortalities in the 
governorate in 2020. It comes in the third rank of the reasons of mortality by $9.1 \%$. Mortality of novel corona virus concentrates in the districts of Abou Tig, and Assiut district by 198 cases in Abou Tig (50.38\%) and 183 cases in Assiut district (46.56\%). El-Badari has 10 mortalities by about $2.5 \%$ of mortality of novel corona virus in the governorate. That is in addition to two cases that are recorded in Dayrout and Sahel Selim.

- The study highlights a rise in the participation of bronchopneumonia by more than $50 \%$ of mortality in the districts of El-Badari, El-Quseya, Manfalout. All mortality cases of this reason concentrates in El_Ghanaim. Respiratory failure records its highest share in El-Fatah, Sahel Selim, and Sadfa by more than $60 \%$ of mortality in these districts. Acute bronchitis records its highest share in Abnoub by about $66 \%$ of the district's fatalities. Novel corona virus shares by $57 \%$ of fatalities in Abou Tig as the highest participation of the pandemic in the burden of mortality of respiratory diseases.

- The highest participation of chest allergy is in Manfalout while Abnoub has the highest participation of asthma. Lung fibrosis and viral pneumonia are dominant in Assiut district. Bacterial pneumonia is dominant in Dayrout while pneumonia of unidentified organisms is dominant in Sahel Selim.

- It is obvious through the study that Abnoub has the highest participation during January by about $6 \%$ of mortality in Assiut governorate. El_Fatah records its highest participation in April and December by about 8.06\% and $7.17 \%$ of the total mortality rate in Assiut governorate. Sahel Selim has its highest share in May and January by 4.46 and $3.14 \%$ respectively. El-Badari records its highest participation in April by 5.2\% while Abou Tig has its highest participation in May. Sadfa has its highest participation during March and November with more than 3.5\%. El-Ghanaim's share exceeds $2 \%$ of mortality cases in the governorate as its highest share is in March, September and November.

- The study highlights a change in the general map of the rates of mortality of respiratory diseases in Assiut governorate and their spatial differences. The general rate reaches 7.12/10000 persons in 2015. Assiut district records the highest rates by more than 10/10000 persons. The least rate is recorded in Manfalout by no more than 4/10000 persons. El_Fatah has a mortality rate of $9 / 10000$ persons. The rate varies between 6:8/ 10000 persons in Dayrout, Abnoub, Abou Tig, Sadfa and El_Ghanaim in 2015. This map witnesses a change over 2020 as the general rate in the governorate rises to $9 / 10000$ persons and leaps to be 24/10000 persons in Assiut district. Next, comes Abou Tig by a rate of 10/10000 persons. The rate decreases in Abnoub, Sahel Selim, ElGhanaim, and Manfalout as it does not go beyond 4/10000 persons. 
- The study shows a change in age structure of mortality of respiratory diseases. Mortality of the age group of 65 years old and more witnesses a noticeable rise in certain districts in the governorate while it decreases in other districts. This age group resembles $54.55 \%$ of mortality rate in Sahel Selim in 2020 while it resembles $36.49 \%$ in 2015. It rises from 23.41 to $46.59 \%$ in Assiut district and from 37.66 to $44.04 \%$ in Abnoub. It also escalates from 38.41 to $48.83 \%$ in El-Fatah and from 17.09 to $20 \%$ in El-Badari. Its mortality rate reaches $45.66 \%$ of the total fatalities in AbuTeij after resembling 30.1\% in 2015.

- Dayrout, El-Quseya, Manfalout, Sadfa and El-Ghanaim witness a reduction in mortality among the age group of 65 years old and more. The highest decrease is in Sadfa where mortality rate among this age group decreases from $51 \%$ in 2015 to $3.7 \%$ of mortality of respiratory diseases in the district in 2020.

\section{Recommendation}

In the light of the previous results, the study recommends to, those responsible for health care in Assiut governorate, the direction of the strategies of disease control to interact with the spatial differences and the changing time trends of respiratory diseases according to the rising in the rates of infection or their fall.

According to this recommendation, it is possible to reduce the rates of infection and mortality of these diseases; through controlling the factors of danger, via reducing the rate of mortality of respiratory diseases and by offering the best chances of remedy. It is obvious that most of the diseases and their geographical differences are influenced mainly by the environmental, civilian and social factors of the different areas and districts. This fact should lead us to the necessity of controlling these diseases not only according to the medical procedures but also by taking into consideration the elements previously mentioned.

\section{References}

1. Abed Alah, M., Abdeen, S. \& Kehyayan, V. 2020, "The first few cases and fatalities of corona virus disease 2019 (COVID-19) in the eastern mediterranean region of the eorld health organization: a rapid review", Journal of Infection and Public Health, vol. 13, pp. 1367-1372.

2. Abolfazl, M., Behrooz, V., Shreejana, B., Laura, C. H., Swagata, B. \& Behzad, V. 2020, "Predicting the hotspots of age-adjusted mortality rates of lower respiratory infection across the continental United States: integration of GIS, Spatial statistics and machine learning algorithms", International Journal of Medical Informatics, vol. 142, pp. 104-114. 
3. Alsabawy, M. 2007, "Medical Geography, Methodology and tools of application", $2^{\text {nd }}$ edition.

4. Bing, X., Jinfeng, W. \& Yang, W. 2021, "Seasonal association between viral causes of hospitalised acute lower respiratory infections and meteorological factors in China: a retrospective study", The Lancet Planetary Health, vol. 10, March 2021.

5. Central Agency of Public Mobilization and Statistics (CAPMS). 2017, "Final reports about the census in Assiut governorate", 2018 edn.

6. Cesar, I., Alvarez, M., Ana, T., Alberto, F. \& Joao, F. 2020, "Spatial estimation of chronic respiratory diseases based on machine learning procedures - an approach using remote sensing data and environmental variables in Quito, Ecuador", Applied Geography, vol. 123, pp.102-115.

7. Chowdhury, S. \& Dey, S. 2016, "Cause-specific premature death from ambient PM2.5 exposure in India: estimate adjusted for baseline mortality", Environment International, vol. 91, pp. 283-290.

8. Directorate of health and population, administration of health affairs. 2021, Unpublished reports, Assiut, Egypt.

9. Egyptian Ministry of Health and population, National information district of the ministry of health, health information systems unit. 2021, Unpublished reports, Assiut, Egypt.

10. El Raies, A. \& Khashaba, M. 2020, "Digital health in facing corona and the alike, about international and Egyptian experiences: A look into the future. National Planning Institute", Chain of Crisis Paper, $7^{\text {th }}$ edn.

11. EPA. 2011, "Climate change -Health and environmental effects". http://www.epa.gov/climatechange/effects/health.html\#ref.

12. Gaber, M. 2003, "Epidemic transformation in United Arab of Emirates, a study in medical geography", Periodicals of Arts and Social sciences, El Kwait, periodical. 24.

13. GBD. 2017, "Mortality, morbidity, and hospitalisations due to influenza lower respiratory tract infections: an analysis for the global burden of disease study", http://dx.doi.org/10.1016/ S2213-2600(18)30496-X.

14. GBD. 2017, "Mortality, morbidity, and hospitalisations due to influenza lower respiratory tract infections, 2017: an analysis for the Global Burden of Disease Study 2017", The Lancet Respiratory Medicine, 12 December 2018.

15. Iuliano, D., Roguski, M. \& Joseph, S. 2017, "Estimates of global seasonal influenza-associated respiratory mortality: a modelling study", The Lancet, vol.14, 14 December 2017.

16. Juliana, M. \& Stefan, B. 2012, "The Health iimpacts of global climate change: A geographic perspective", Applied Geography, vol. 33, pp 1-3.

17. Kazory, A., Ronco, C. \& McCullough, P. A. 2020, "SARS-CoV-2 (COVID19) and intravascular volume management strategies in the critically Ill. Baylor University", Medical District Proceedings, pp. 1-6, https://doi.org/10.1080/08998280.2020.1754700.

18. Kobi, P., Moran, B., Attila, J. H. \& Thomas, D. 2021, "The COVID-19 pandemic challenge to the all-hazards approach for disaster planning", International Journal of Disaster Risk Reduction, vol. 55, pp.102-103. 
19. Kuo, F. \& Hung Wen, T. 2021, "Regionalization for infection control: An algorithm for delineating containment zones considering the regularity of human mobility", Applied Geography, vol.126, 102375.

20. Onafeso, D., Tolulope, E. O., Glory, T. O. , Michael, O. F., Adeyemi, Oludapo O., Adeolu, O. D., Adegbayi, M. H., Sakinat, O. F., Samuel A. \& Efosa, A. 2021, "Geographical trend analysis of COVID-19 pandemic onset in Africa", Social Sciences \& Humanities, vol. 4, pp.100-137.

21. Raslan, W.E. 2020, "Fractional mathematical modeling for epidemic prediction of COVID-19 in Egypt", Ain Shams Engineering Journal .xxx (xxxx) xxx.

22. Sahai, V., Donaldson, M.D., Alicia, N., Thomas, M.D., Richard. F., Gillum, M.D., \& Alem Mehari, M. D. 2021, "Geographic variation in racial disparities in mortality from influenza and pneumonia in the United States in the precoronavirus disease 2019 Era", Chest Infections Original Research, CHEST.

23. Schneider, C., Merbitz, H., Buttstädt, M., Michael, S. \& Dott, W. 2012, "GIS-based identification of spatial variables enhancing heat and poor air quality in urban areas", Applied Geography, vol.33, pp. 94-106.

24. Sharaf, A. 2003, "Environment and man's health in medical Geography". Alexandria book Center, $2^{\text {nd }}$ edn.

25. Shouraseni, S. R., Robert, C. B. \& Balling J. 2021, "Impact of the cOVID-19 lockdown on air quality in the Delhi metropolitan region", Applied Geography, vol. 128, pp.102-118.

26. Siyan, D., Changke, W. \& Qing, W. 2020, "Projecting Impacts of Temperature and Population Changes on Respiratory Disease Mortality in Yancheng", Physics and Chemistry of the Earth, Parts A/B/C28.

27. Stefan, S., Niketa, U. \& Christian, H. 2020, "Mathematical Modeling of COVID-19 Fatality trends: Death Kinetics Law Versus Infection-to-Death Delay Rule". Chaos, Solitons \& Fractals, 30 May 2020.

28. Sun, Y., Koh, V., Marimuthu, K., Ng, O.T., Young, B., Vasoo, S., Chan, M., Lee, V.M., De, P.P., Barkham, T., Lin, R.T.P., Cook, A.R. \& Leo, Y S. 2020, "Epidemiological and clinical predictors of COVID-19", Clinical Infectious Diseases, https://doi.org/ 10.1093/cid/ciaa322.

29. Townsend, J. 2015, "Mapping disease transmission risk: Enriching Models Using Biogeography and Ecology", Emerging Infectious Diseases, vol 21, 1489. https://doi.org/ 10.3201/eid2108.150665

30. Venter, Z.S., Aunan, K., Chowdhury, S. \& Lelieveld, J. 2020, "COVID-19 lockdowns cause global air pollution declines with implications for public health risk", https://www.medrxiv.org/content/10.1101/2020.04.10.20060673v1.article-metrics.

31. Viana, J., Vasco Santos, J., Manuel Neiva, R., Souza, J., Duarte, L. \& Cl'audia Teodoro, A. 2017, "Remote sensing in human health: A 10-year bibliometric analysis", Remote sensing, https://doi.org/10.3390/rs9121225.

32. Vibhu, P., Rajat, K. \& Pankaj, A. 2020, "Trends and Geographic Variation in Acute Respiratory Failure and ARDS Mortality in the United States", Chest.

33. WHO. 2020, "Modes of transmission of virus causing COVID- 19: implications for IPC precaution recommendations", Scientific brief, pp.1-3. https:// doi.org/10.1056/NEJMoa2001316.5. 
34. Wisdom, M.D., Sabelo, N.D., Sizwe D.M. \& Sabelo, P.S. 2020, "Spatial risk assessment of an emerging pandemic under Data Scargovernorate: A case of COVID-19 in Eswatini", Applied Geography, vol. 125, 102358.

35. Wu, X., Nethery, R.C., Sabath, B.M., Braun, D. \& Dominici, F. 2020, "Exposure to air pollution and COVID-19 mortality in the United States", medRxiv,

https:// www.medrxiv.org/content/10.1101/2020.04.10.20060673v1.article-metris.

36. Wu, Y.C., Chen, C.S. \& Chan, Y.J. 2020, "The Outbreak of COVID-19: An overview", Journal of the Chinese Medical Association, vol. 83, pp. 217-220. https://doi.org/10.1097/JCMA.0000000000000270. 


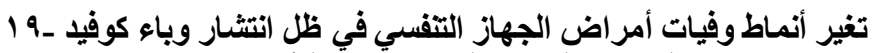

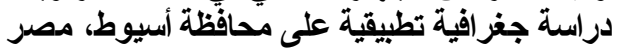

$$
\text { أحمد علي أحمد علي }
$$ \\ مدرس في قسم الجغرافيا ونظم المعلومات الجغرافية،$$
\text { كلية الآداب - جامعة أسيوط }
$$

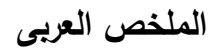

تعد أمراض الجهاز التتفسي من الأسباب الرئيسية للوفاة, ومن أكثر الأمراض التي ترتفع بمعدلات المراضة والدخول بالمسنشفيات, وهي ترتبط بالعديد من العوامل البيئية والاقتصادية والاجتماعية والسلوكية, وتتباين موسميتها بمتغيرات مناخية, وقد شهت خريطتها التوزيعية والنسبية تغيراً على المستويات المكانية والزمانية؛ ونلك في ظل انتشار متلازمة الجهاز التتفسي المعروفة بفيروس كورورنا المستجد (كوفيد-9 ()), والذي يشكل أكبر التحديات التي نتج عنه تفشي أمراض الجهاز التتفسي على مستوى العالم, وقد انتشر

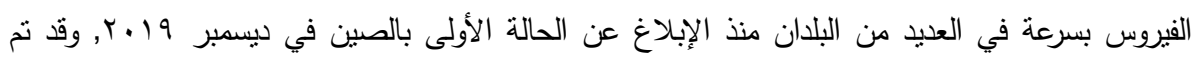

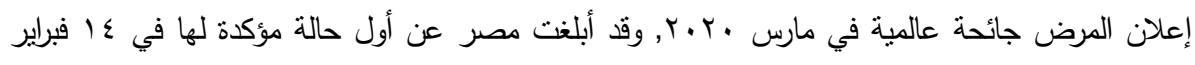

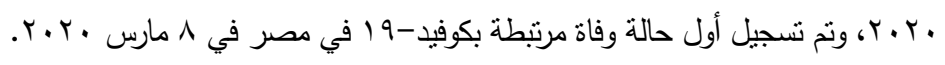
ويهدف البحث إلى تحليل التغيرات والتباينات المكانية والزمانية والديموجرافية التي طرأت على حجم فرئم وفيات أمراض الجهاز التتفسي في محافظة أسيوط, والتغيرات في أنماطها وتوصيف أسبابها؛ بما يفيد في تحديد حجم الوفيات والزيادة التي طرأت عليها والمحتمل أن تكون له علاقة بتفشي الوباء؛ والتي يمكن أن نكون حالات لم يتم فحص إصابتها من عدمها, وتعد هذه الدراسة بمثابة دراسة وصفية تحليلية ضمن العديد من ون

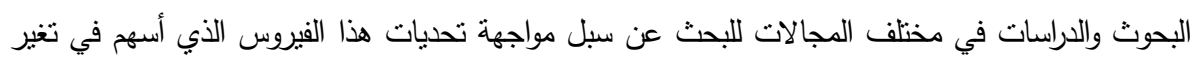
خربطة وفيات أمراض الجهاز التتفسي. وتسهم معرفة التوزيع الجغرافي وحجم الوفيات وتغير أنماطها واختلافاتها الجغرافية والزمانية في تحسيد

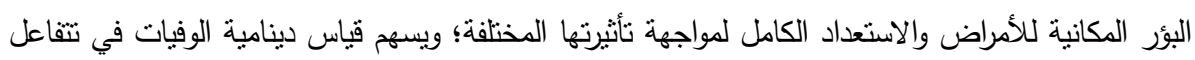
إستراتيجيات الرعاية الصحية مع الاتجاهات المتغيرة واستعدادها لمجابهة زيادة معدلات الإصابة أو انخفاضها؛ حيث يعد تحديد خرائط خطورة أمراض الجهاز التتفسي بشكل عام والتعرض لكوفيد-19 أمراً ضرورياً لدعم الأني الجهود المبذولة لرفع مسنوى الوعي لدى السكان والمراقبة لدى الجهات المسئولة, وتوجية أقسام الحجر الصحي

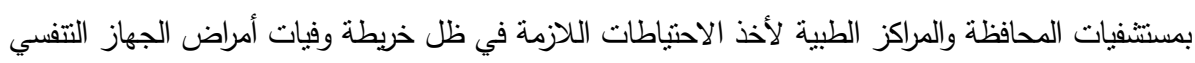
في المحافظة. الكلمات الافتتاحية: أمراض الجهاز التتفسي, وباء كوفيد 9 ا , أنماط الوفيات, محافظة أسيوط. 